\title{
Targeting Glycoproteins as a therapeutic strategy for diabetes mellitus and its complications
}

\author{
Rozita Naseri ${ }^{1}$ - Seyed Jafar Navabi ${ }^{1} \cdot$ Zeinab Samimi $^{2} \cdot$ Abhay Prakash Mishra $^{3} \cdot$ Manisha Nigam $^{4} \cdot$ Harish Chandra $^{5}$. \\ Ahmed Olatunde $^{6} \cdot$ Habibu Tijjani ${ }^{7} \cdot$ Raquel P. Morais-Urano ${ }^{8} \cdot$ Mohammad Hosein Farzaei $^{2}$ (D)
}

Received: 25 July 2019 / Accepted: 10 January 2020/Published online: 31 January 2020

(C) Springer Nature Switzerland AG 2020

\begin{abstract}
Objectives Glycoproteins are organic compounds formed from proteins and carbohydrates, which are found in many parts of the living systems including the cell membranes. Furthermore, impaired metabolism of glycoprotein components plays the main role in the pathogenesis of diabetes mellitus. The aim of this study is to investigate the influence of glycoprotein levels in the treatment of diabetes mellitus.

Methods All relevant papers in the English language were compiled by searching electronic databases, including Scopus, PubMed and Cochrane library. The keywords of glycoprotein, diabetes mellitus, glycan, glycosylation, and inhibitor were searched until January 2019.

Results Glycoproteins are pivotal elements in the regulation of cell proliferation, growth, maturation and signaling pathways. Moreover, they are involved in drug binding, drug transportation, efflux of chemicals and stability of therapeutic proteins. These functions, structure, composition, linkages, biosynthesis, significance and biological effects are discussed as related to their use as a therapeutic strategy for the treatment of diabetes mellitus and its complications.

Conclusions The findings revealed several chemical and natural compounds have significant beneficial effects on glycoprotein metabolism. The comprehension of glycoprotein structure and functions are very essential and inevitable to enhance the knowledge of glycoengineering for glycoprotein-based therapeutics as may be required for the treatment of diabetes mellitus and its associated complications.
\end{abstract}

Keywords Glycoprotein $\cdot$ Biological activities $\cdot$ Glycosylation $\cdot$ Diabetes mellitus $\cdot$ Proteins

Abbreviations
Asn
Cys
DA
EPO

Abhay Prakash Mishra abhaypharmachemhnbgu@gmail.com

Mohammad Hosein Farzaei mh.farzaei@gmail.com

1 Internal Medicine Department, Kermanshah University of Medical Sciences, Kermanshah, Iran

2 Pharmaceutical Sciences Research Center, Health Institute, Kermanshah University of Medical Sciences, Kermanshah, Iran

3 Department of Pharmaceutical Chemistry, Hemwati Nandan Bahuguna Garhwal (A Central) University, Srinagar Garhwal, Uttarakhand 246174, India
ER Endoplasmic reticulum

FSH Follicle stimulating hormone

GalNAc N-acetyl-D-galactosamine

GalNAc-transferases $\mathrm{N}$-acetylgalactosaminyltransferases

GlcNAc N-acetyl-D-glucosamine
4 Department of Biochemistry, Hemwati Nandan Bahuguna Garhwal University, Srinagar Garhwal, Uttarakhand 246174, India

5 Department of Microbiology, Gurukul Kangri Vishwavidhyalya, Haridwar, Uttarakhand 249404, India

6 Department of Biochemistry, Abubakar Tafawa Balewa University, Bauchi, Nigeria

7 Natural Product Research Laboratory, Department of Biochemistry, Bauchi State University, Gadau, Nigeria

8 Instituto de Química de São Carlos, Universidade de São Paulo, 13560-970 São Carlos, SP, Brasil 


$\begin{array}{ll}\text { GlcNAc transferase } & \begin{array}{l}\text { N-acetylglucosamine transferase } \\ \text { GPI }\end{array} \\ \text { hCG } & \begin{array}{l}\text { Human chorionic } \\ \text { gonadotropin hormone }\end{array} \\ \text { IFN- } \beta & \text { Interferon beta } \\ \text { IL-5 } & \text { Interleukin 5 } \\ \text { MAbs } & \text { S protein-specific } \\ & \text { monoclonal antibodies } \\ \text { MHV } & \text { Murine hepatitis virus } \\ \text { P-glycoprotein } & \text { (P-gp) } \\ \text { Pro } & \text { Proline } \\ \text { PTMs } & \text { Post-translational modifications } \\ \text { rHuEPO } & \text { Recombinant human erythropoietin } \\ \text { Ser } & \text { Serine } \\ \text { SLE } & \text { Systemic lupus erythematosus } \\ \text { Thr } & \text { Threonine } \\ \text { UDP-GalNAc } & \text { Uridine } \\ \text { diphosphate-N-acetylgalactosamine } \\ \text { UDP-GlcNAc } & \text { Uridine } \\ & \text { diphosphate-N-acetylglucosamine }\end{array}$

\section{Introduction}

Diabetes mellitus is burgeoning its hands worldwide. It has been documented that diabetes was the leading cause of death accounting for 1.5 million death in 2012, whereas in 2014 around 422 million people suffered from it [1]. Diabetes complications include diabetic ketoacidosis (DKA), strokes, heart disease, fatigue, diabetic retinopathy, and diabetic retinopathy, etc. [2]. Diabetes exists in two forms, i.e. diabetes mellitus and diabetes insipidus. Out of these two conditions, most of the people are suffering from type 2 diabetes mellitus (DM2 or T2DM). The leading responsible cause of T2DM is a sedentary life style, genetic makeup, bad food habits, lack of physical activity and obesity. The prevalence of diabetes has been reported to be comparable in low versus high-income countries in 2018 [3].

A plethora of factors contributes to the progression of T2DM. However, the mutation in genes involved in the regulation of glucose uptake and metabolism can enhance the risk of diabetes in the gene carriers. These genes are TCF7L2 (responsible for insulin secretion and glucose production), ABCC8 (responsible for insulin regulation), CAPN10 (associated with T2DM), GLUT2 (involved in the movement of glucose in the pancreas) and GCGR (associated with glucagon hormone).

Glycoproteins are a vital form of biomolecules that participate in numerous types of physiological and abnormal conditions. These protein-carbohydrate compounds exist in many forms of vital importance such as hormones, enzymes, membranes, and antibodies. Over the years, glycoproteins have gained increasing interest due to the biological significance as they have implicated indirectly or directly in disease conditions, including diabetes mellitus [4, 5].

Furthermore, it is well established that glycosylation affects the inherent features of proteins such as antigenicity, stability, immunogenicity, and conformation [6]. The carbohydrate moiety of glycoproteins has several biological functions such as cell adhesion, development, immune responses, trafficking, hostpathogen interactions and signaling [5, 7-9]. N-glycosylation is essential in endoplasmic reticulum (ER)-related breakdown cascade, quality control and in protein folding mediated by lectin $[10,11]$. Lysosomal enzymes are specific in recognizing and selecting the different abnormal substances over others due to the presence of Mannose-6-phosphate (M6P)-labelling as a marker $[12,13]$. Recognition of glycoproteins displayed on the cell membrane surface is employed by pathogens in the modulation of the host immune response during viral and bacterial infections [14-18]. Furthermore, the progression of diseases like autoimmune and cancer disorders inhibit the process of glycosylation [19-21]. Interestingly, Monoclonal antibodies among other vital therapeutic proteins are glycosylated and their existence, as well as sugar chain structures, are essential for their stability and biological actions [22, 23]. Accordingly, comprehending the structure and functions of glycoproteins are very essential and inevitable. Therefore, this study aims to delineate the structure and biological roles of glycoproteins in diabetes mellitus emphasizing their involvement in the regulation of this disorder.

\section{Pathogenesis of Diabetes mellitus : Cellular and molecular insights}

\section{Type 1 diabetes}

Type 1 diabetes mellitus (T1DM) also known as insulin dependent diabetes mellitus (IDDM) is influenced by genetic and environmental factors [24], resulting in the autoimmune destruction of $\beta$-cells responsible for the production of insulin in the pancreas. Plethora of environmental factors (enteroviruses, toxins or dietary factors) over a span of months to years might similarly trigger the development of T-cell dependent autoimmune activities in genetically susceptible persons. Moreover, during this period sufferer are asymptomatic but positive for autoantibodies. T1DM has been reported to affect males and females equally [25] while declining the life expectancy by approximately 13 years [26]. The article will give detail genetic, immunologic and environmental factors that ultimately destroy $\beta$-cells in the pancreas resulting in insulin deficiency.

\section{Genetic Factors:}

Type 1 diabetes represents about $10-15 \%$ occurrence in individual who have first or second degree relative with 
diabetes and may normally occur in individuals without any family history of diabetes. However, a significant increase in the risk of developing T1DM is more in relatives of patients compared to the general population [27-29]. More interestingly, if a patient's parent has T1DM, the risk for developing T1DM is $5 \%$ and it becomes higher if, among the parents, the father is the diabetic patient [30]. Reports have identified more than 50 genetic risk loci related to T1DM [31] whereas gene variants occurring in a major locus named major histocompatibility complex (MHC) region, also known as human leukocyte antigen (HLA) [32] have similarly been reported to confer between $50-60 \%$ of genetic risk associated with T1DM development [33]. The genetic risk is linked with the expression of the gene by affecting the HLA protein ability to bind to antigenic peptides and their antigen presentation to $T$ cells [34]. It has been reported that an additional 50 genes contribute as smaller effects to T1DM individually [35].

The polymorphisms occurring at the region coding insulin gene Ins-VNTR promoter and that of a cytotoxic $T$ lymphocyte-associated antigen-4 gene (CTLA-4) are reported to account for between $10-15 \%$ genetic risks to T1DM. CTLA-4 gene is critical in ensuring overall immune responsiveness by coding a molecule which plays a significant role in maintaining the functionality of T-cells [36]. CTLA-4 polymorphism has been linked with T1DM and with other gene related autoimmune diseases as well [37]. Besides, other genetic associations that have influence on T1DM are numerous and include Autoimmune regulator (AIRE), Erb-B2 receptor tyrosine kinase 3 (ERBB3), Forkhead box P3 (FoxP3), Huntingtin-interacting protein 14 (HIP14), Interferoninduced helicase $\mathrm{C}$ domain 1 (IFIH1), Interleukin (IL)-2 receptor- $\alpha$ (ILR2A), Protein tyrosine phosphatase nonreceptor type 22 (PTPN22), as well as Signal transducer and activator of transcription 3 (STAT3) [37].

\section{Epigenetic Factors:}

It has been reported that epigenetics contributes significantly to T1DM [38]. Epigenetic modification including DNA methylation exists at cytosine residues primarily in the context of $\mathrm{CpG}$ dinucleotides. Disease associated with $\mathrm{CpG}$ sites can be identified with several approaches including systematic epigenome-wide association studies (EWASs) applied to quantify differences in the DNA methylation at $\mathrm{CpG}$ sites between cases and controls, which are differentially termed methylated $\mathrm{CpG}$ positions (DMPs). Further studies with DMPs have shown they associate with a multitude of complex traits and other diseases including T1DM [39, 40].

Genome-wide DNA methylation quantitative trait locus (mQTL) analysis in human pancreatic islets was performed to reveal genome-wide associations between genetic and epigenetic variations. It was documented that such mechanisms influence islet mRNA expression, function and thus potential risk of diabetes [41]. Studies had demonstrated that several candidate genes (GPX7, GSTT1, and SNX19) directly influence critical biological processes and functions including proliferation and apoptosis in pancreatic $\beta$ cells. Approximately, $90 \%$ of the causal variants in T1DM are noncoding with estimated $\sim 60 \%$ mapping to immune-cell enhancers and many of which gain histone acetylation and transcribe enhancer associated RNA after immune stimulation [42]. In a study to explore the cellular and molecular changes in islets of pancreas and $\beta$ cells in response to immunological stressors (proinflammatory cytokines), it was reported that epigenetic modification (methylation of insulin DNA) may be a mechanism by which insulin gene expression is affected during the progression of T1DM in nonobese diabetic mice [43]. Moreover, to explain discordance of T1DM in identical twins through differential epigenetic variation it was reported that there is an enrichment of differentially variable $\mathrm{CpG}$ positions (DVPs) in T1DM twins as compared with other healthy co-twins and with healthy, unrelated individuals, thus hinting the role of epigenetic changes and their associations with the pathogenesis of T1DM [44].

\section{Environmental factors}

The continuous increase in global incidence, integration of local disease occurrence rates when migration from a region of low-incidence to a region of high-incidence countries and variance in geographic prevalence, all support the involvement of environmental factors [45]. Environmental factors in corroboration with genetic factors triggers also trigger autoimmunity leading to subsequent progression into T1DM, as supported by the fact that individuals living with the highest-risk HLA haplotypes are not observed to develop T1DM [29]. However, the extreme exposures to environmental conditions triggers in the first few years of life may also be critical as suggested by evidences from the early age of the onset of islet autoantibodies actions in childhood-onset of T1DM. However, the variability of age at the disease onset may complicate the study of its effects on environmental exposures.

Viral infection is another mechanism implicated in the occurrence of diabetes, however, there is no direct evidence reported as a particular strain of virus being link to cause T1DM [46]. Interestingly, it has been documented that exposure during fetal life to rubella has been shown to increase the incidence of T1DM and other autoimmune disorders [37]. Data from epidemiological studies have strongly suggested the involvement of coxsackievirus B (an enterovirus) in T1DM development as evident from the presence of RNA or proteins from such enteroviruses in pancreas and some other neighboring tissues from T1DM patients. Enteroviruses infect the $\beta$ cells and activate innate immunity and inflammation in the early phase of T1DM. Although as an antiviral protein, virus-induced interferon alpha acts as initiators towards 
autoimmunity directed against pancreatic $\beta$ cells and this can be deleterious. Moreover, enteroviruses can interact effectively with adaptive immune system by successive or through persistent infections [47]. Host genes, such as IFIH1 which encode melanoma differentiation-associated protein 5 (MDA5), influence susceptibility of individuals to T1DM. Reports have shown that an upward activity of the IFIH1 protein activities may promote T1DM development. Once viral infection occurs, MDA5 proteins provoke the proliferation of mediators of the innate antiviral immune response, thus acting as a cytoplasmic sensor to viruses, more especially coxsackieviruses B [48, 49]. In a study to explore the relationship between autoimmunity, insulitis, viral infection, $\beta$ cell function and survival in T1DM, islets from six recent-onset T1DM patients were studied. Enterovirus was found to be able to infect $\beta$ cells in T1DM patients, which is associated with inflammation and functional impairment [50]. Viruses may also induce an autoimmune response by using mechanisms like molecular mimicry, a phenomenon involving the sharing of antigenic properties between $\beta$ cells and environmental agents. Thus immune responses are directed against autoantigens which resemble the actual viruses' antigens and results in their cellular destruction [37]. P2-C protein of Coxsackie B4 virus, for example, is significantly similar in their amino acid sequence to glutamic acid decarboxylase (GAD65) enzyme which is found in $\beta$ cells of endocrine pancreas [37].

Among the environmental associations, the importance of diet is still a matter of debate. For example, a study documented that at early age administration of dairy products consumption and that of high milk during early childhood increase the levels of antibodies in cow's milk and that high IgA antibodies in cow's milk formula increase the risk of T1DM independently [50]. It was documented that a peculiar part of the albumin from cow's milk, called the ABBOS, which contain 17 peptides, can function as a self-reactive epitope because of its resemblance to another $\mathrm{p} 69$ protein found in at surface of pancreatic $\beta$ cells [51]. Moreover, the ingestion of plants based nutrient elements provided the notion of a link between T1DM and earlier exposures of cereals into the diet [52] and gluten [53]. Inadequate intake of omega-3 fatty acids has also been studied in association with T1DM [54]. Nitrate administration from water intake [55] and toxic doses of nitrosamine compounds may also result in diabetes via generation of some free radicals but it is unclear if dietary nitrate, nitrite, or nitrosamine exposure on human T1D could act in the same manner [56]. Many perinatal risk factors which are seen in childhood diabetes are also linked with T1DM [57] like maternal - child blood group incompatibility, pre-eclampsia, neonatal infections and respiratory distress, maternal age, gestational age, birth weight and order [58-61].

Recent data indicate that altered gut microbiomes have also implications in the pathogenesis of T1DM as evident by the differences in the gut microbiome profile of T1DM versus healthy controls [33]. Previous studies have reported that as healthy infants approach the toddler stage their microbiomes are seen to be healthier and even more stable. However, in children who are destined for autoimmunity usually develop a microbiome with less diversity and stability. Therefore, autoimmune microbiome identified with T1D may be specifically different from that existing in healthy children [62]. It has been known that dietary exposure is the regulator of the immunity and self-tolerance by changing gut microbiome [63]. Even the lack of contact between vaginal microbiome and interferon-induced helicase gene polymorphisms in the Caesarian section indicate the possible protective role during normal labor and vaginal delivery because such children show subsequent gut microbiota differences themselves [64].

\section{Immunologic factors}

Immunological factors could also contribute to the pathogenesis of diabetics mellitus. Disorders associated with routine immune mechanisms may result in autoimmunity that could lead to T1DM. Organ-specific autoimmune disease could cause an autoimmune response against host pancreatic $\beta$ cells. T1DM is similarly complicated often times with other autoimmune diseases and presence of anti-islet autoantibodies precede the clinical onset of disease. The occurrence of anti-islet autoantibodies (islet cell antibodies, ICA) in patients diagnosed with autoimmune polyendocrine syndrome was first analyzed in 1974 [65]. Later, researchers reported target autoantigens against ICA, insulinoma-associated antigen-2 (IA-2), glutamic acid decarboxylase (GAD) and more recently against zinc transporter 8 (ZnT8) [66-68]. Individuals exhibiting positivity for single autoantibody most often revert to negative, however, reversion is not common in people with multiple autoantibodies [69]. The risk of development of T1DM in children with HLA risk genotypes or with their relatives who have been diagnosed with T1DM, is said to occur in two or more islet autoantibodies at $75 \%$ within 10 years [70], where the risk increases with the increasing numbers of autoantibodies [70, 71]. The concurrent expression of two or up to three autoantibodies acts as the markers of progression into clinical T1DM [72]. Recently, a study into TEDDY (the environmental determinants of diabetes in the young) funded by the National Institutes of Health, look into individuals who had already established two or more autoantibodies. Krischer et al. suggested that the risk of progression from multiple autoantibodies disorders to T1DM was not seen different among those with or even without a family history of the disease. They also indicated that this was higher in female gender, when a few high-risk HLA-DR and HLA-DQ subtypes are present while their study indicated an inverse relationship to the age of first appearance of positive autoantibodies in the family [73]. The presence of islet autoantibodies 
illicit immune response on B- and T-cell to the antigens present on $\beta$-cell leading to their loss and function. This eventually leads to initiation of glucose intolerance, a stage prior to onset of diabetes clinical symptoms. $\beta$ cell destruction in T1DM occurs most probably via programmed cell death (apoptosis). Autoreactive T lymphocytes induce inflammatory reactions with the expression of high levels of proinflammatory cytokines IL-1, INF- $\gamma$ (interferon- $\gamma$ ) and TNF- $\alpha$ (tumor necrosis factor- $\alpha$ ) within the islet that activates the caspase cascade. Moreover, other researchers suggested that apoptosis is induced directly from the contact of autoreactive $\mathrm{T}$ lymphocytes with $\beta$ cells through the Fas/Fas ligand interaction or perforating system $[74,75]$. Chronic inflammation within the islets occurs involving $\mathrm{T}$ and $\mathrm{B}$ lymphocytes, macrophages and dendritic cells prior to the onset of T1DM that evolves over many months or years with asymptomatic and euglycemic patients. Clinical manifestation of the disease or symptomatic high glucose level (hyperglycemia) occurs after an extended latency period, which is reflected by the destruction of a large number of functioning $\beta$ cells [76]. It has been reported that mutations in the autoimmune regulator (AIRE) gene resulting from recessive Mendelian disorder autoimmune polyendocrinopathy syndrome type 1 (APS-1) and APS-1 patients develop multiorgan autoimmune diseases are included in T1DM. The expression of the AIRE protein is key to control the central tolerance induction in the thymus leading to the regulation of the expression levels of tissue-specific peripheral antigens, including insulin [77]. Viral infections can affect thymic epithelial cells and thymocytes. This can be seen with coxsackievirus B4 virus and some other enteroviruses resulting in abnormalities of the differentiation processes of T cells and their maturation [78].

Recently it has been documented that reduction in the functional capacity of different regulatory $\mathrm{T}$ cells (Tregs) populations contributes in T1DM development possibly by the fact that IL-2 signaling plays in maintaining FOXP3 expression, thus maintaining Treg fitness. It has been reported that Treg-intrinsic defects observed in T1DM may be due to relative reduction in IL2 signaling [79].

\section{Type 2 diabetes}

Type 2 diabetes (T2DM) also known as Non-insulin dependent diabetes mellitus (NIDDM) is a multifactorial disorder resulting by a combination of multiple genetic factors linked to abnormal insulin secretion, insulin resistance and number of environmental factors including physical inactivity, stress, obesity and aging [80]. Type 2 diabetes is not classified as an autoimmune disorder and the genes implicated in predisposing individual to NIDDM have not been identified because of the heterogeneity of the genes responsible for the susceptibility to disease. Like T1DM, there are various factors contributing to the pathogenesis of NIDDM, which include environmental factors, epigenetics, and genetic factors.

\section{Genetic factors}

The pathogenesis associated with type 2 diabetes mellitus (T2D) is characterized firstly by impaired insulin secretion and secondly by insulin resistance. It has been reported that the lifetime risk of onset of type 2 diabetes is approximately $40 \%$ if a parent out of two has type 2 diabetes and More so, higher if the mother, in particular, is affected by the disease [81]. The genetic factors associated with $\mathrm{T} 2 \mathrm{DM}$ is greater when compared with T1DM [82]. A population-based Cohort study of twins in Finland to access the concordance of diabetes mellitus has shown that probandwise and pairwise concordance rates for T2DM were found to be $34 \%$ and $20 \%$ among monozygotic twins and $16 \%$ and $9 \%$ among dizygotic twins respectively. They documented that the heritability for T1DM was greater than that for T2DM indicating that both environmental and genetic factors seemed to play a critical role [83]. Further studies on the effects of environmental and genetic factors indicated that genetic factors play roles that are more important in the pathogenesis of diabetic than environmental factors $[84,85]$.

Even with the extensive research and research outputs, the genetic framework of T2D risk has not yet been well explored [86]. Small percentage of non-autoimmune diabetes representing $5 \%$ or less are due to monogenic causes, which is referred to as monogenic diabetes of the young (MODY). Such type of cases is reported to be resulted by the most common mutations in glucokinase (GCK) gene and hepatocyte nuclear factor-1A (HNF1A) [87]. Unlike T1DM, the genetic component of T2DM involves interaction of multiple genes. Linkage studies have reported calpain 10 (CAPN10) and transcription factor 7-like 2 (TCF7L2) are associated with T2DM. CAPN10 is a cysteine protease from the calpain family and its functions include the multiple roles it plays in intracellular remodeling and other intracellular functions. It was the first T2DM gene to be discovered through linkage analysis [88].

Surprisingly in candidate gene studies, most of the genes identified to be associated with insulin secretion and action did not pose associated risk with T2DM. Insulin receptor substrate 1 (IRS1) and insulin receptor substrate 2 (IRS-2) are among the few genes that were found to be linked with T2DM [89]. Others are HNF1 homeobox A and B (HNF1A and $1 B$ ) and $H N F 4 A$ [90], peroxisome proliferator-activated receptor gamma $(P P A R G)$ [91], potassium inwardly-rectifying channel, subfamily J, member 11 (KCNJ11) [92] and Wolfram syndrome 1 (wolframin) (WFS1) [93].

Genome-wide association studies (GWAS) has strongly confirmed the link between T2DM and a number of singlenucleotide polymorphisms (SNPs) occurring in different 
ethnicity where this gene remains the most replicated and documented to be the most strongly associated T2D risk gene[94]. It has been found in GWAS that genes associated with the increased risk of obesity also contributes to the development of T2DM like FTO and MC4R [86]. TCF7L2, a most consistently replicate T2D susceptibility gene was discovered as in a Mexican-American population [95]. The gene encodes a transcription factor, which is active in the $\beta$ cells. It was reported that (Lyssenko) TCF7L2 associated T2DM risks are conferred by various mechanisms, including decreased $\beta$ cell insulin response and decreased insulin sensitivity in target tissues such as adipose tissue, increased the level of TCF7L2 protein in $\beta$-cells.

Besides, hematopoietically expressed homeobox (HHEX), insulin-like growth factor 2 mRNA binding protein 2 (IGF2BP2), cyclin-dependent kinase inhibitor $2 \mathrm{~A}$ $(\mathrm{CDKN} 2 \mathrm{~A}) /$ cyclin-dependent kinase inhibitor 2B $(C D K N 2 B)$, solute carrier family 30 (zinc transporter) and member 8 (SLC30A8) are some other genes linked with the pathogenesis of T2DM.

However, some other genes associated with T2DM risk include CDK5 regulatory subunit associated protein 1-like 1 (CDKAL1), high mobility group AT-hook 2 (HMGA2), Notch 2-ADAM metallopeptidase domain 30 (NOTCH2-ADAM30), potassium voltage-gated channel and KQT like subfamily, member 1 (KCNQ11) but their specific role in the pathogenesis of T2DM is still unknown.

\section{Epigenetics}

Epigenetic mechanisms have been shown to predispose individuals to the diabetes mellitus [96]. On the contrary in T2DM, prolonged dyslipidemia, hyperglycemia and increased oxidative stress that results in altered homeostasis could lead to epigenetic changes [97]. DNA methylation in the transcriptional coactivator PPARGC1A promoter (involved in glucosestimulated insulin secretion) is elevated in islets of T2DM patients leading to decreased PPARGC1A expression [98] thus suggesting that epigenetic mechanisms could be involved in the regulation of insulin secretion by human islets. Aging has also been linked to be associated with an increased risk of T2DM [97]. The epigenetic pattern could change during the lifespan affecting key respiratory chain genes such as part of complex four of the respiratory chain (COX7A1). COX7A1, an age-related DNA methylation target expression is decreased express in diabetic skeletal muscle [99]. COX7A1 in human skeletal muscle is associated with elevated in vivo glucose uptake and $\mathrm{Vo}_{2 \max }$. The data obtained from these studies demonstrate influence of age on gene expression, DNA methylation and their subsequently in vivo metabolism. Pancreatic islet $\beta$-cell proliferation may declines after birth, but proliferation of $\beta$-cell might play an important role in islets adaptation to increased insulin loads imposed by insulin resistance. It has been reported that an elevated expression of Ink4a/Arf ( $C d k n 2 a$ locus) has been linked with reduced regeneration of $\beta$-cell [100]. The increased Ink4a/Arf expression in aged mice further concurred with reduced levels of histone H3 lysine 27 trimethylation at Ink4a/Arf and the histone methyltransferase (Ezh2), with correspondence decrease in Bmi-1 binding and expression of loss of H2A ubiquitylation at Ink4a/Arf [101, 102]. The common variant occurring at the $C D K N 2 A$ locus is linked with increased risk for T2DM [103].

Recently It has been documented that the detected enhanced expression of methyl-CpG binding domain2 (MBD2) proteins in T2DM patients at different stages of T2DM development indicated that a general dysregulation occurs in DNA methylation. Out of many of the studied stress and cell cycle regulation genes, consistently five of the genes have been shown to be increasingly methylated with increase in T2DM duration as seen in Prdx2, BRCA1, SCARA3, Tp53, and CCND1. The elevated methylation of genes $\operatorname{Prdx} 2$ and SCARA3 indicated their role in oxidative stress protection declines due to elevated methylation and might lead to T2DM complications. Genes $T p 53, C C N D 1$, and BRCA1 are related to tumorigenesis thus linked T2D with cancer development as well [96].

\section{Environmental factors}

The environmental factors of the pathogenesis of T2DM include aging, alcohol drinking, insufficient energy consumption, obesity and smoking which are in independent risk factors of the disease. Out of these factors, obesity is the major risk factor for T2DM [104, 105] with complex genetic and environmental etiology. The deposition of ectopic fat in the muscle and liver leads to Insulin resistance. The fats may also accumulate in the pancreas and significantly contribute to islet inflammation, decline in $\beta$-cell function and eventually $\beta$-cell death [106]. It has been reported that weight loss improves insulin sensitivity [107] and may prevent the accumulation of pancreatic fat [108]. Furthermore, the only three replicated loci namely MTNR1B, PREX1, and FTO have been found common in both obesity and T2DM. The Pro12Ala polymorphism in PPARG (playing a role in adipogenesis) may modulate the risk of T2DM. Reports have shown that the expression of PPARG in adipose tissue of obese subjects is increased [109].

Epidemiological studies indicate that long-term exposure to pollutants (herbicides and pesticides) disturbs glucose metabolism and induces insulin resistance. It has been reported that there is a dose-dependent relationship between the serum concentration of organic pesticides and prevalence of diabetes [110]. Interestingly, obesity could serve as a storage house for such toxic organic pollutants due to their lipophilic profile, which induce insulin resistance and eventually T2DM in a dose- and time-dependent order [111, 112]. Exposure to air 
pollutants also is associated with higher incidence rates of T2DM [113], predominantly in women (higher risk) possibly by inflammation in adipose tissue and insulin resistance [114]. The highest exposure correlates with a $>20 \%$ increase in T2DM prevalence after modifying for other risk co-factors which includes education, ethnicity, health insurance, income, indoor pollutant exposures, obesity, population density and smoking [115]. Other chemical contaminants in water or food and occupational exposures to an array of toxins have been reported to be linked with risk of T2DM and mortality. Due to limited number of studies, and small samples these data are still inconclusive [116]. Oxidative stress also contributes to the development of insulin resistance, as the inverse association which exists between plasma vitamin $\mathrm{C}$, serum carotenoids and plasma tocopherol concentrations (as markers of vegetable, fruit intake or dietary supplements) with T2DM and impaired metabolism of glucose has been detected [117, 118]. Therefore, antioxidants might confer protection against T2DM [119].

\section{Gestational diabetes}

Gestational diabetes mellitus (GDM) is hyperglycemic metabolic disorder that is onset or first recognized during pregnancy, where there is no evidence of pre-existence of T1DM or T2DM [120]. The risk factors associated with GDM are reported to be similar to those of T2DM, which include dyslipidemia, ethnicity, and family history of diabetes, hypertension, increasing age, obesity, and polycystic ovary syndrome.

GDM normally disappears after delivery but women with previous diagnosis of GDM are at a higher risk of development of gestational diabetes in their subsequent pregnancies and T2DM later in life [121]. Insight into the exact mechanisms of GDM development is still being sought. One of the possible basis for development of GDM is obesity as reflected by the percentages $(10 \%)$ of pregnancies. It has been documented that women having GDM generally have higher BMI (body mass indices) and obesity leading to chronic low-grade inflammation that induces the biosynthesis of xanthurenic acid, associated with the development of pre-diabetes, T2DM and GDM [120].

The insulin requirements during normal late pregnancy are usually higher. However, GDM women regularly express reduced insulin response to nutrients [122]. Furthermore, the majority of women diagnosed with GDM show $\beta$-cell dysfunction due to chronic insulin resistance already present before pregnancy [123]. Moreover, insulin signaling alterations, decreased expression of PPAR $\gamma$ and decreased insulinmediated glucose transport has also been reported in women with GDM [124]. Diabetes and obesity lead to post-receptor abnormalities in insulin signaling in placenta of women [125]. Since the fetus pose an antigenic load, it was proposed that its event triggers the development of GDM. Human leukocyte
antigen-G (HLA-G) expression which functions to safeguard the fetus from possible immune attack which is achieved by down-regulating the responses of cytotoxic $\mathrm{T}$ cell to fetal trophoblast antigens, is postulated to also protect pancreatic islet cells. The interaction between nuclear factor $-\mathrm{KB}(\mathrm{NF}-\mathrm{kB})$ and the HLA-G is suggested to play a key role in GDM development. [126]. Moreover, as in T1DM, defects associated with $\beta$-cell function could also result from autoimmune destruction of the pancreatic $\beta$-cells responsible for production of insulin in GDM women and such occurrence in subjects could lead to rapid development in overt diabetes soon after pregnancy [127]. Additionally, mutations in genes which leads to several subtypes of MODY have been observed in women with GDM (account for less than $10 \%$ of all GDM cases) that include mutations in encoded genes for glucokinase, hepatocyte nuclear factor $1 \alpha$ and insulin promoter factor 1 [124].

\section{Glycoproteins: structure, composition, and biological effects}

\section{Glycoprotein structure}

Glycoproteins are organic compounds formed from proteins and carbohydrate interaction existing as specific compounds. The carbohydrates are extensively more compounded than proteins and nucleic acids, which are macromolecules bearing main biological information. Glycome is the spectrum of all glycan structure and it is immense. This indicates that the number of proteins coded by genome is less than the number of glycan structure in order of magnitude [128]. Figure 1 shows a simple illustration of the structure of glycan linked to a polypeptide.

However, carbohydrates are ever present in nature and there are few doubts that the detailed carbohydrate fashions seen on the top of cells and proteins are crucial in apprehending and appreciating several multiplex biological processes. For instance, glycoproteins played essential roles in processes like neuronal development, inflammatory responses, fertilization, immune surveillance and hormone activities [129-133]. Also, pathogens use the carbohydrates of the host cell as means of entry and immunological evasion.

Normally, the proteins are covalently attached to the carbohydrates [134] and majority of the proteins that exist in nature are in the form of glycoproteins. Glycoproteins are found in many parts of the living systems such as the cell membranes. However, these compounds produced by cells and found on cell boundaries are used as markers to determine the biochemical compounds.

Usually, proteins are mainly synthesized in a cell organelle called the endoplasmic reticulum (ER) whilst the glycan addition occurs inside an intracellular membrane cascade made up of secreting vesicles, Golgi apparatus, endoplasmic 
Fig. 1 The structure of simple sugar residues that exist in glycoproteins

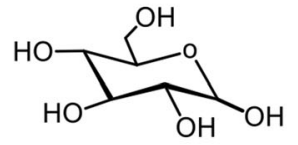

Glucose

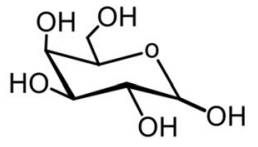

Galactose

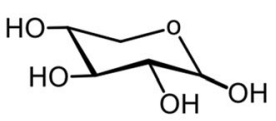

Xylose

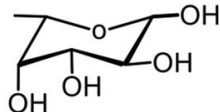

Fucose<smiles>O=C(CO)N[C@H]1C(O)CC(O)(C(=O)O)OC(C(O)CO)C1O</smiles>

N-glycolneuramic acid

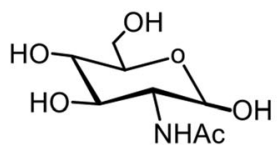

$\mathrm{N}$-acetylglucosamine

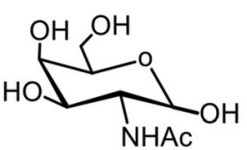

$\mathrm{N}$-acetylgalactosamine<smiles>CCNC(O)C1C(O)CC(O)(C(=O)O)CC1C(O)CO</smiles>

$\mathrm{N}$-acetylneuramic acid

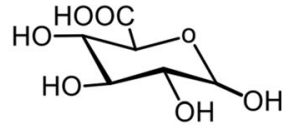

Glucuronic acid reticulum, and transfer vesicles. The produced proteins are normally isolated from the cytosol via protein translational process, after which they are moved to outside of the cell [135]. Ribonucleases, chorionic gonadotropin, and plasma proteins are examples of biologically active glycoproteins. The performance of many biological identification systems is as the result of the vital sequence of the glycans found in glycoproteins [136]. Also, the glycans are responsible for metabolites throughout the pores of nucleus $[137,138]$.

\section{Glycoproteins composition and linkages}

The carbohydrates found in glycoproteins are in the form of massive heteropolysaccharides or non-complex disaccharides made up of about 15 - 20 simple sugars [139, 140]. Sialic acid, D-glucose, xylose, glucuronic acid, N-acetyl-Dgalactosamine (GalNAc), D-mannose, N-acetylneuraminic acid, L-fucose, N-acetyl-D-glucosamine (GlcNAc) and Dgalactose are the types of carbohydrate units found in glycoproteins (Figure 1).

Eukaryotes have several proteins that are glycoproteins, which are constituted with chains of oligosaccharide that are covalently bonded to specific amino acids. However, this is different from glycation [141], which is defined as a nonenzymatic reaction between glucose units with amino acids to form a hybridized compound and normally occurs in an uncontrolled or untreated hyperglycemia. On the other hand, glycosylation takes place in biological systems with the inclusion of enzymes. Also, it is seen in cell-cell interaction, protein folding, trafficking, and localization of protein, antigenicity, protein solubility, and biological activity [129, 142, 143]. In addition, protein glycosylation also takes place in prokaryotic cells.

Different glycoproteins have different amounts and percentages of glycan units. These bonds are of two types based on the sugar added to a specific functional group of an amino acid [144, 145]. Glycosylation of protein can be categorized into four major classes based mainly on the interaction between the sugar moiety and amino acid. These include $\mathrm{N}$ linked glycosylation, O-linked glycosylation, glycophosphatidylinositol anchor attachments (GPI) and Cmannosylation [146].

\section{$\mathrm{N}$ - and O-linked glycosylation}

The glycan in glycoprotein can be bonded to an amide nitrogen atom of asparagine to form an $\mathrm{N}$-linked glycosidic bond or found attached to the oxygen atom on threonine or serine to form an O-linked glycosidic linkage. Thus, NAcetylgalactosamine (GalNAc) linked to Ser/Thr units are found in glycoproteins where the carbohydrates are bound to protein by $\mathrm{O}$-linkage while $\mathrm{N}$-linked carbohydrates are linked to glycoproteins by N-Acetylglucosamine (GlcNAc) bond to asparagine unit [137, 138, 147]. Hence, the O-glycosylation is characterized by a sugar moiety bonded to the hydroxyl group of Ser or Thr unit while N-glycosylation has an amide group of asparagine (Asn) amino acids linked to the sugar moiety [146].

The O-linked glycosylation may occur at two sites in a cell. This includes the glycosylation process occurring in the Golgi bodies. In this organelle, hydroxyl amino acids normally Ser/ Thr are initially linked to different reducing terminal linkages (monosaccharide residues) like glucosamine, phosphodiester 
linked GlcNAc, GalNAc, mannose, glucose, xylose, fucose or galactose (Figure 1). This usually causes the formation of branched oligosaccharides structures, which have an impact on the adhesive features on the membrane and secreted glycoprotein.

Previously, it has been indicated that the process of $\mathrm{O}$ glycosylation takes place in the cytosol and nucleus of cells $[148,149]$. Thus, the hydroxyl group of Ser/Thr unit is linked to monosaccharide, like GlcNAc. O-glycosylation of membrane and secreted bound proteins occurs in the Golgi compartment of the cis-form after $\mathrm{N}$-glycosylation and protein folding [150, 151]. However, O-glycans are accumulated in a clockwise pattern with carbohydrates added one after another to form a growing branch. The cytoplasmic glycosylation where one simple sugar is attached is an exception (Figure 2). O-glycosylation has no defined acceptor motif. But the main regular feature of many O-glycosylation sites is that they are seen on the Ser and Thr units near proline (Pro) moieties, with the acceptor site normally in a $\beta$-configuration [146].

\section{Mucin type glycosylation (O-GaINAc)}

In mammals, the common type of O-glycosylation is the Mucin type glycosylation, where GalNAc is linked to Ser/ Thr units of cell membrane surface and secreted proteins with further addition of GlcNAc, Gal or GalNAc residues. This process is catalysed by $\mathrm{N}$-acetylgalactosaminyl transferases (GalNAc-transferases) from a family of uridine diphosphate$\mathrm{N}$-acetylgalactosamine (UDP-GalNAc). In several cells and organs, these enzymes are distinctively expressed and have alternating specificities for substrates [143, 152].

\section{O-a-GIcNAc glycosylation}

This type of O-glycosylation is found in simple eukaryotes and the O-GlcNAc units are normally arranged in two different configurations to the backbone of the peptide. The two conformations are alpha anomeric conformation and $\beta$ anomeric conformation. The alpha configuration is represented as $\mathrm{O}-\alpha$-GlcNAc units, which are found mostly on secreted and membrane proteins while the $\beta$ configuration is represented as $\mathrm{O}-\beta$-GlcNAc residues, which are seen on nuclear or cytoplasmic proteins. The process of attachment of O- $\beta$ GlcNAc is known as O-GlcNAcylation. Dictyostelium discoideum is a predictor developed for O- $\alpha$-GlcNAc sites [146].

\section{O- $\beta$-GIcNAc glycosylation}

O- $\beta$-GlcNAc glycosylation is the type of O-linkages found on nuclear or cytoplasmic proteins. It was later observed that $\mathrm{O}$ glycosylation is not mainly confined to proteins, which goes into an endoplasmic reticulum cotranslational modification.
However, this glycosylation also takes place on cytoplasmic or nuclear proteins. Furthermore, multiple site modification alongside a single $\mathrm{N}$-acetylglucosamine unit (O- $\beta$-GlcNAc) is exhibited by cytoplasmic and nuclear glycoproteins [153]. In this form of O-glycosylation, the linkage in nuclear/ cytoplasmic proteins is through a $\beta$ anomeric linkage to give $\mathrm{O}-\beta$-GlcNAc sites. Nuclear pore complex has a high level of $\mathrm{O}-\mathrm{GlcNAcylated} \mathrm{proteins.} \mathrm{The} \mathrm{O-GlcNAcylation} \mathrm{is} \mathrm{seen} \mathrm{as} \mathrm{a}$ fluidic process, which leads to rates higher than the protein backbones [154, 155]. Ser/Thr are the acceptor sites for OGlcNAcylation and are located closely to proline normally in a $\beta$ configuration.

\section{Glycosylphosphatidylinositol (GPI) anchor}

Proteins are covalently attached to glycolipids called glycosylphosphatidylinositol (GPI) as a posttranslational modification [156]. This leads to anchoring of the protein to the outside surface of membrane. Hence, Proteins that are garnished with GPIs have special features in terms of their physical appearance [156] and giving rise to GPI anchor with O-linked GlcNAc proteins. Studies indicated that the backbone structure of GPI anchor is preserved among eukaryotic organisms including yeast, plant, and mammals. The conserved backbone structure is ethanolamine phosphate-6Man $\alpha 1$ 1 Man $\alpha 1-6$ Man $\alpha 1-4$ GlcN $\alpha 1-6$ myoinositol-phosphate (Maeda and Kinoshita, 2011). The biosynthesis of GPI and the attached protein as a posttranslational modification to form GPI anchor takes place in the ER [157].

Furthermore, the N-linked carbohydrates are subdivided into three major forms, including complex, high mannose and hybrid [134, 158, 159]. The three categories of N-linked glycan are derived from a template oligosaccharide constituting GlcNAc2Man9Glc3. The amide group of an Asn unit is co-translationally bonded to Dol-P-GlcNAc2Man9Glc3 precursor. This co-translational addition of oligosaccharide takes place in the ER and this is seen to have an impact on protein folding and the requirement for the $\mathrm{N}$-glycosylation is the sequence motif of Asn-Xaa-Ser/Thr (where Xaa represents any amino acid except proline) [160]. While another rare sequence motif of Asn-Xaa-Cys has been indicated to behave as an acceptor site [161]. Some researchers reported that the AsnXaa-Ser acceptor motif is not well used compared to motif Asn-Xaa-Thr [162]. Moreover, oligosaccharyltransferase is the enzyme required for the addition of $\mathrm{N}$-linked precursor to amino acids, it is situated in the ER, and this action is conserved process of evolution in eukaryotic organisms. A ring structure can be formed by an Asn-Xaa-Ser/Thr by which the basic unit of the oligosaccharyltransferases can act upon [163]. Two $\alpha$-linked core mannose units are found in the hybrid glycans, the high mannose has only GlcNAc core and mannose residue while the complex glycoproteins have 
altered digit branches. GlcNAc unit is found at least in each branch [163].

\section{Complex N-linked glycan}

Complex N-linked glycans of plants occur from the Golgi bodies of high mannose $\mathrm{N}$-linked glycan via the action of specific glycosyltransferases and glycosidases. They are characterized by the existence of $\beta(1,2)$-xylose and/or $\alpha(1,3)$-fucose units bond to $\beta$-mannose units and proximal GlcNAc. This occurs in the presence of $\alpha$-mannose residue linked to $\beta(1,2)$ GlcNAc units. The formation of this N-glycoform differs from eukaryotes to eukaryotes during the developmental stages. The sequence motif described above is a requirement for glycosylation but it is not enough for this enzymatic process [146]. Currently, additional $\beta(1,3)$-galactose and $\alpha(1,4)$ fucose units are bonds to the GlcNAc residue.

\section{High mannose $\mathrm{N}$-linked glycan}

High mannose N-linked glycans were initially found in soybean plants with agglutinin. The N-linked was bound to different vascular and extracellular glycoproteins. In addition, these types of glycan exist as the specific N-linked oligosaccharides of spinach $[164,165]$. An example of high mannose $\mathrm{N}$-linked glycan contains repeated structure unit of mannose linked by N-linked glycan $\left(\mathrm{Man}_{5}-\mathrm{GlcNAc}_{2}\right.$ to $\left.\mathrm{Man}_{9} \mathrm{GlcNAc}_{2}\right)$ structure [166].

\section{Hybrid N-linked glycan}

C-mannosylation involves the linkage of an alpha mannopyranosyl unit to a tryptophan moiety at indole $\mathrm{C} 2$ position through a C-C linkage [167]. They are normally seen on the initial tryptophan in motif of sequence $\mathrm{W}-\mathrm{X}-\mathrm{X}-\mathrm{W}$. Also, in other cases such as W-X-X-C and W-X-X-F [168, 169]. The formation of hybrid N-linked glycan varies during development inside eukaryotic cells [146]. The structure of hybrid N-linked glycan may contain GlcNAcMan (Xyl)(Fuc)GlcNAc 2 [166].

\section{Paucimannosidic N-linked glycan}

Paucimannosidic N-linked glycan is formal to be modified insect N-linked glycans with non-terminal GlcNAc units bond to $\alpha$-mannose units of the core [170]. Based on Lerouge et al. [166] report, the name Paucimannosidic N-linked glycan was proposed to represent modified plant oligosaccharides constituted with alpha $(1,3)$-fucose or/and $\beta(1,2)$-xylose unit link to the proximal GlcNAc and $\beta$-mannose units to the restricted Man2GlcNAc2 core or of the core Man3GlcNAc2. This Nlinked glycan resulted from the removal of terminal units from
Fig. 2 Structures showing glycan-amino acid bonds existing in glycoproteins (a) complex N-linked glycan, (b) core 2 O-glycan, (c) Glc-NAcylation, (d) proteoglycan bond, (e) bond structure of GPI proteins. In several situations, the simple sugar residues in the structure above can accommodate more carbohydrate or different non-carbohydrate alterations. Wavy line represents amino acid sequence. Adapted from [177].

a complex N-linked glycan and can be seen as typical vacuoletype N-linked glycans [171].

Glycoproteins can further be classified based on their functions into different groups, including collagen (structural proteins), transferring and ceruloplasmin (transport proteins), patatin (enzyme), calnexin and calreticulin (influence folding of some molecules), mucins (protective and lubricant molecule), lectins and selectins (interactive molecules) [172, 173].

Protein glycosylation is the covalent attachment of monosaccharides or oligosaccharide residues to proteins. It is one of the mainly occurring post-translational modifications (PTMs). Current discoveries have shown that the process of protein glycosylation does not only occur in eukaryotic cells but also take place in some prokaryotic cells, including archaea, fungi and bacteria [166, 174]. Protein glycosylation can be more a complex phenomenon that is functionally and structurally diverse compared to most other PTMs like phosphorylation, which normally has to do with simple, transfer of simple, functional groups to one or many amino acid units [5].

About forty different types of carbohydrate-amino have been shown to have at least eight different amino acid units and thirteen different proximal simple sugars $[175,176]$. On the other hand, microorganism shows verse trace simple sugar residues in secondary metabolites, amazingly, not more than a dozen of monosaccharides is seen in typical glycoproteins in eukaryotes. But, building blocks of limited quantity can still produce unprecedentedly large structures as a result of bid possibilities of bond types, additional noncarbohydrate decorations of sugar lengths or/and anomeric stereochemistry [177].

Glycans are linked to the protein via three vital types of bonds in glycoproteins found in eukaryotic systems. As stated earlier, one of the linkages is the N-linked glycosylation where the oligosaccharide is linked to an amide side chain of asparagine unit in a concurrence (Asn-Xaa-Ser/Thr) sequence. The Xaa could be any of the naturally occurring amino acids except proline via the linkage of pGlcNA $\beta 1$-Asn. The O-linked glycosylation has its sugar linked to the hydroxyl $(\mathrm{OH})$ group of serine or threonine unit in the protein backbone. The mucintype O-glycoproteins represents the O-glycosylation, where the $\mathrm{O}$-glycans are linked to the proteins via a preserved linkage of GlcA $\beta 1,3-G a l \beta 1,3-G a l \beta 1,4-X y 1 \beta 1-S e r$ bond. Thus, the O-glycans are bonded to protein through proteoglycans where large glycosaminoglycans are linked to the protein through the preserved GlcA $\beta 1,3-G a l \beta 1,3-G a l \beta 1,4-X y l \beta 1$ Ser bond. 

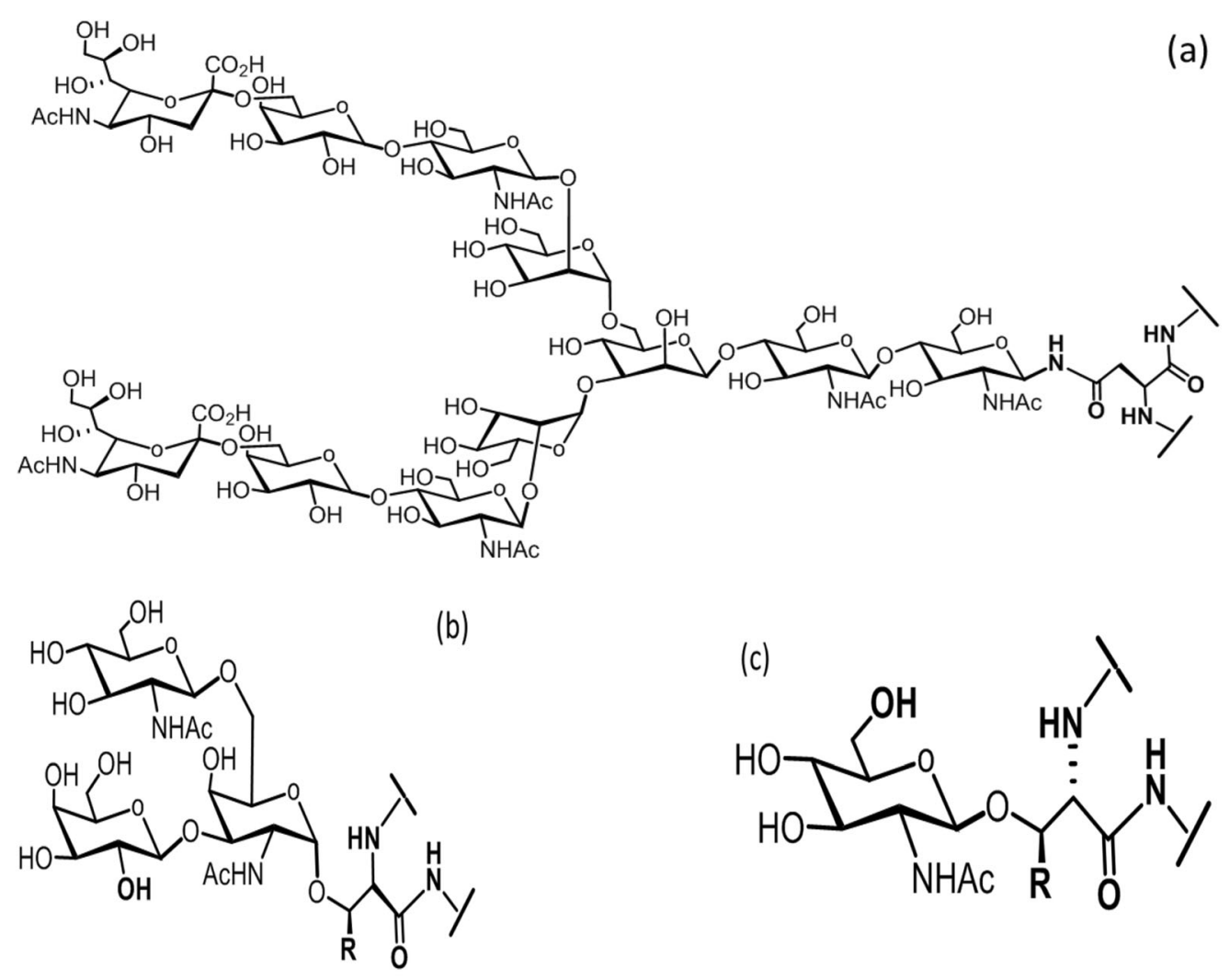

(d)
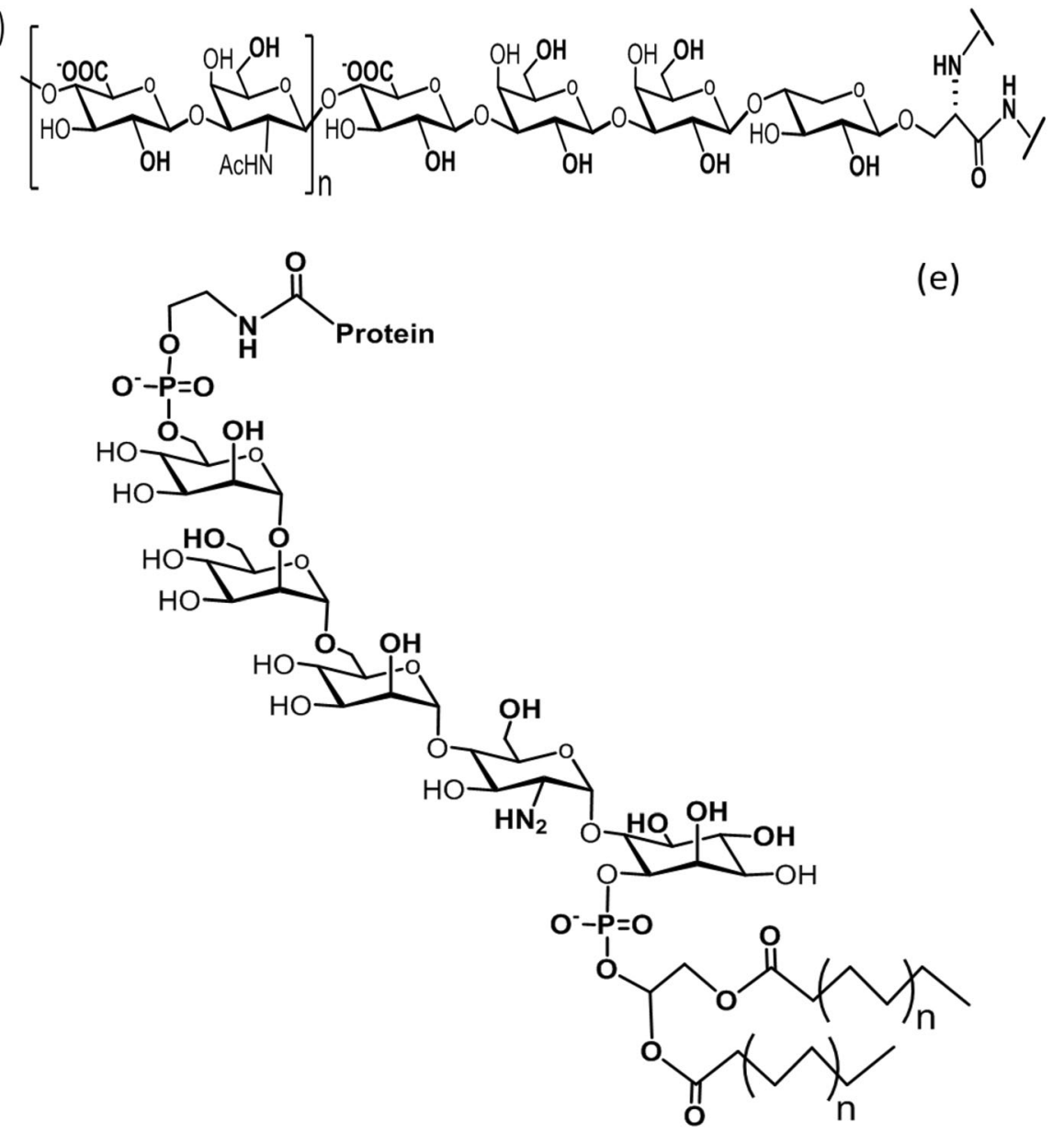
However, several proteins are attached to the membrane via certain GPI-anchor, which finds the proteins at the cell tops for actions. Apart from the attachment of groups like O-glycans, $\mathrm{N}$-glycans or GPI anchors, simple sugars used for glycosylation have been shown to play vital role as seen by O-GlcNAc glycosylation of several cytoplasmic and nuclear proteins controlling the transduction of signals [178, 179].

\section{Glycoproteins biosynthesis}

The biosynthesis of common O- and N-glycoproteins normally involves several steps consisting of large amounts of enzymes like the glycosidases, glycosyltransferases and other sugar modifying enzymes except in the attachment of simple sugar units like O-GlcNAc glycosylation that has to do with the transfer of simple sugars to the protein by the action of GlcNAc transferase involving uridine diphosphate-Nacetylglucosamine (UDP-GlcNAc) as the substrate. For instance, N-glycoproteins biosynthesis in eukaryotes is carried out in several steps in the Golgi apparatus and ER compartment of cells. In the ER with several glycosyltransferases, a big oligosaccharide template (Glc3Man9GlcNAc2) is aligned on a lipid carrier called dolichol [177]. A multi-subunit oligosaccharyltransferase mediates the transfer of dolichollinked oligosaccharide to amide group of Asn side on the ribosome and in a concerted sequence Asn-Xaa-Ser/Thr of a growing polypeptide. Subsequently, the template is processed to specific glycoform of monoglucosylate (Glc1Man9GlcNAc2) which is used in the protein folding linked associated with calnexin/calreticulin chaperone, which is responsible for the control of quality protein. Once the precursor (Glc3Man9GlcNAc2) is properly folded, it is further trimmed to Man8GlcNAc2-protein in the ER within its lumen and then transported to the Golgi bodies to produce several glycoforms including complex, high mannose and hybrid type glycotypes. In species-, proteins-, and/or cell type-site specific manner, several glycosyltransferases, and glycosidase catalyses the N-glycans processing. Diverse and different glycoprotein glycotypes are synthesized as a result of sensitivity of the physiological state of cells and differential expression of the enzymes involved [177].

However, apart from the N-glycosylation process that start with the arrangement of big oligosaccharide template structure, O-glycan biosynthesis take place in a clockwise pattern beginning with the binding of the GalNAc as the first sugar to the hydroxyl group $(\mathrm{OH})$ of Ser/Thr unit via an $\alpha$-glycosidic bond catalysed by polypeptide GalNAc transferase (ppGalNAcT). This process occurs in the Golgi apparatus (Li and Wang, 2018). Sequential addition of simple sugars further elongates the sugar chain catalyzed by respective glycosyltransferase to give different O-glycan core structures. However, various ppGalNAcT indicate some selectivity to polypeptide sequence for the binding of the GalNAc residue. O-glycosylation has no concurrence sequence. All the enzymes partaking in the biosynthesis of $\mathrm{O}$ and N-glycans can be explored for purposes of synthesis [177].

\section{Importance of glycoproteins}

Glycosylation of protein has been like with the functions of glycoproteins, among which are their ability to block viral induction, neutralize their infectivity, or cell-to-cell fusion. Glycoproteins are of cell proliferation, growth, maturation and signaling pathways. They are similarly involved in drug binding, drug transportation, efflux of chemicals and stability of therapeutic proteins. These are further discussed below using examples.

Glycoproteins assist in forming a strong tissue by linking cells together in the body. For example, hormones are glycoproteins, which play a critical role in erythrocyte replication among other hormonal functions. Glycoproteins are also seen in connective tissues and in the bones. Vital molecules like vitamins are normally transported in the body with the help of several glycoproteins. Similarly, they help in regulating molecules that are responsible for breaking down proteins in the body. Alteration of receptors found in human tongue in order to facilitate the identification of stale food as well as sweet food is determined by glycoprotein called Miraculin. Antigens are acted on by glycoproteins in the body called the antibodies. Glycoproteins also aggregate ordinary platelets together and link them to the endothelium. Furthermore, in mammals, they are vital for the detection of white blood cells [163].

\section{Cytokine and humoral factors}

Cytokines and humoral factors are glycoproteins with varied numbers of carbohydrate chains, which varies in their structures. The major biological functions are typically the properties of the protein components, while the carbohydrate components are majorly responsible for their molecular stability, solubility, in vivo activities, immunogenicity and their halflife [180]. More so, the serum half-life of therapeutic proteins are extended by the sialic components of their carbohydrates [180].

Breastfeeding is important in infants. Breast-fed infants show fewer or less severe respiratory and gastrointestinal infections during the first year of life compared with formulated infants feed [181-183]. Human milk is different as regards to content of their complex oligosaccharides compared with milk from other species [184]. These milk components, including the oligosaccharides, as well as glycoproteins, have been believed to 
play a critical role during the development of specific intestinal flora in breast-fed infants. They are effective as inhibitors of bacterial adhering to epithelial cell surface at the initial stage of infection [185], thus playing a considerable role as soluble receptor analogues of the epithelial cell-surface carbohydrate [185].

\section{Coronavirus glycoprotein}

Coronaviruses are positive strand RNA viruses, which are associated with diseases in both animals as well as humans [186]. The features, nucleic acid sequence, and genomes of coronavirus have been long determined [187]. Murine coronavirus (murine hepatitis virus [MHV]), for example, contains a genomic RNA with more than $30 \mathrm{~kb}$ [188], encoding four major structural proteins which are nucleocapsid protein (50 to $60 \mathrm{kDa})$, hemagglutinin-esterase glycoprotein $(65 \mathrm{kDa})$, a membrane glycoprotein (23 to $26 \mathrm{kDa}$ ) and spike or surface glycoprotein (180 kDa) [189]. The MHV surface glycoprotein forms projecting peplomers on the surface of the virus particle. The function of the spike during virus maturation includes the recognition of basic sequence located approximately in the middle of the viral polypeptide [190]. Some S protein-specific monoclonal antibodies (MAbs) generated neutralize virus infectivity, block virus-induced and cell-to-cell fusion [191].

\section{Reelin glycoprotein}

Reelin glycoproteins are secretory serine protease [192], which function in the mammalian brain as a guide to neurons and radial glial cells to their correct positions in the developing embryonic brain[193]. Reelin glycoproteins are involved in signaling pathway, which triggers neurotransmission, synaptic plasticity, and memory formation. The disruption of signaling pathway in reelin has been linked to the formation of neuropsychiatric disorders such as schizophrenia or autism following selective hypermethylation and mutations of the Reln gene promoter or by prenatal or postnatal insults leading to the observed cognitive deficits [193].

\section{P-glycoprotein}

P-glycoproteins are 170-kDa transmembrane protein, which are encoded by the gene called multidrug resistance phenotype (MDR1). P-glycoproteins are expressed in various tissues, among which are the peripheral blood lymphocytes [194]. They are efflux pumps to decrease the concentration of intracellular accumulation of variety of immunosuppressants and lipophilic drugs, including cyclosporine A, anthracyclines, glucocorticoid, quinidine, tacrolimus, and vinca alkaloids [195]. P-glycoprotein therefore functions in protecting cells from their exposure to such lipophilic drugs and aiding the developing resistance to them.
Treatment of systemic lupus erythematosus (SLE) involves the use of some immunosuppressive drugs. Increase in Pglycoprotein expressed in lymphocytes during SLE has been linked to influence disease outcome or level of steroid required for the disease control [196]. Reports have also correlated the expression of P-glycoprotein in peripheral lymphocytes with total prednisone dose in children suffering from nephrotic syndrome [197].

\section{Biological effects of glycoproteins}

The many biological efficacies of human therapeutic glycoproteins are depended on the properties of protein or carbohydrate structures. For examples, the oligosaccharide content of glycoproteins is responsible for many physical properties, biological activities, serum half-life, immunogenicity, thermodynamic and stability of proteins.

\section{Physical properties}

The physical properties and stability of therapeutic proteins are of importance to activities. Protein components of glycoproteins are responsible majorly for their biological activities, while the carbohydrate components play key roles in the molecular stability [180]. Carbohydrate content of fibronectin, interleukin 5 (IL-5) and interferon $\beta$ (IFN- $\beta$ ) play key role in their stability. Fibronectin is more sensitive to proteolysis without their carbohydrate, while IL-5 carbohydrate stabilizes its molecular conformation when exposure to heat. Similarly, carbohydrates are responsible for the decreased sensitivity of glycosylated IFN- $\beta$ compared to unglycosylated IFN- $\beta$ [198-200]. The biological effects of carbohydrate in glycoproteins have also been demonstrated using glycoengineering. For instance, mucins are heavily O-glycosylated, and express an increase in their gel-like properties due to the presence of high sialic acid content. Additional of more carbohydrates through $\mathrm{N}$-linkage to native sequence leptin through glycoengineering [201], increase the solubility of the resultant glycosylated leptin over several folds compared with the native leptin [180]. Another example has been demonstrated with recombinant human erythropoietin ( $\mathrm{rHuEPO}$ ) on the role of carbohydrate in maintaining their molecular stability and protection from free radicals. Asialo-rHuEPO (without sialic acid) and fully deglycosylated rHuEPO lost them in vitro biological activities when heat-treated, however, glycosylated rHuEPO lose no activity upon same heat treatment [202]. Similarly, Unglycosylated rHuEPO are denatured easily by treatment with heat, $\mathrm{pH}$, and guanidine- $\mathrm{HCl}$ while glycosylated rHuEPO remains soluble and displays reversible folding, unlike aggregates and precipitates formed from the previous treatment in unglycosylated rHuEPO [203, 204]. More so, the carbohydrate component of $\mathrm{rHuEPO}$ has been identified to 
protect peptide components from the adverse effects of free oxygen radicals [205].

\section{Biological activity}

Erythropoietin (EPO) glycosylation analogs have demonstrated a direct and positive relationship between their in vivo activities and number of carbohydrate chains [206]. Some of the factors that further affect these activities include the number and position of the attached carbohydrate chains, with number of carbohydrate playing a more significant role [180].

Contribution of carbohydrate to the biological activities of glycoproteins has been demonstrated using the glycoengineering of rHuEPO in a hyperglycosylated analogue Darbepoetin alfa (DA) [201]. The carbohydrate/sialic acid content of rHuEPO has direct proportions with its bioactivities and serum half-life [207]. While DA and rHuEPO have similar conformation and stability, the addition of more carbohydrate to DA did not blunt the biological response from various intracellular signaling that were examined [201]. Similarly, the role of glycosylation of glycoprotein to enhance their in vivo activities is demonstrated by leptin. Leptins are nonglycosylated protein responsible for the regulation of body weight. Glycoengineered leptin analog which is rich in carbohydrates (GE-LeptinL4-58) administered to obese mice, caused more weight loss and maintained their reduced weight, which was observed for a longer period of time compared with unglycosylated recombinant human leptin [201]. In general, carbohydrate may influence the specific activities of glycoprotein by affecting the glycoprotein tertiary structures, or affect the ligand-receptors interactions through steric effects or perhaps through a charge effect related to the presence of sialic acids on the oligosaccharides of their ligands or receptors or both [208, 209].

\section{Circulatory half-life}

Oligosaccharides play important roles in the in vivo glycoprotein clearance rate and critical to the properties determining their efficacy in therapeutic proteins [208]. The rate at which the therapeutic proteins are cleared from circulation determines their specificity be rated high activities when clearance is low and low activities when clearance is high.

Follicle stimulating hormone (FSH) is a gonadotropin hormone secreted by the gonads. FSH is clinically used in the treatment of infertility and seizure of ovulation in women with polycystic ovary syndrome [180]. The structure of FSH consists of two subunits with N-linked glycosylation sites, and isoforms that are rich in sialic acid content. The high sialic acid content in a particular isoform has been found to increased its in vivo bioactivity and reduce renal clearance [210, 211]. Glycosylated interleukin 3 (IL-3) reportedly increased by $30 \%-40 \%$ ability to stimulate the activities of the enzyme histidine carboxylase found in bone marrow after a single injection when compared with the non-glycosylated forms. The observed increase in activities due to the increase in the serum half-life of the enzyme [212]. For EPO, the specific activities are increased upon desialylation, while rapid in vivo clearance mere the in vivo activities [213, 214]. Glycoprotein oligosaccharides affect clearance rate by mechanism, which is, not attributed to high-affinity receptors [208].

\section{Immunogenicity and antigenicity}

Addition of carbohydrate to peptide molecule have decreased their immunogenicity. Reduction in immunogenicity was observed in both Plasmodium falciparum merozoite surface protein 1 and wasp venom peptide following the addition of carbohydrates [215]. Generally, carbohydrates may reduce immunogenicity of therapeutic proteins compared with nonglycosylated therapeutic proteins [180]. More so, oligosaccharide can contribute directly or indirectly to glycoprotein antigenicity [216]. Oligosaccharide structure can serve as antibody recognition site [217]. The sequence $\operatorname{Gal} \alpha(1,3) \mathrm{Gal} \beta$ $(1,4)$ GlcNAc epitope represent a specific terminal recognize by immunoglobulin $\mathrm{G}$ (IgG) [218].

\section{Assembly and orientation}

Effects of carbohydrates on the assembly and orientation of proteins have been demonstrated using human erythrocyte CD59 cell-surface glycoprotein. The CD59 binds to CD9 or CD8, presented on a wide variety of cells [219]. The orientation of the glycoproteins is such that it contains N-linked glycosylation site, several O-linked glycans, and a GPI-anchor. The N-linked glycoforms are highly heterogeneous, consisting of more than a hundred complex-types. The glycan seems to play major roles in affecting CD59 and binding affinity, indicating that the glycan affects cell surface packaging of proteins and prevents their aggregation on the cell surface. Hydrophilic type of glycan, are proposed to limit interaction of the protein with lipid bilayer and in turn facilitation their diffusion along cell membranes [220]. N-linked glycosylation affects structure, stability, and assists in the assembly of oligomeric complexes, which enable the orientation of cell surface glycoproteins to cell surface [220].

\section{Stability and thermodynamic}

Carbohydrate plays a significant role in the stability and thermodynamics of proteins. Glycoproteins demonstrate more stability compared with unglycated proteins [220] and reduce the disorder associated with unfolded protein. Carbohydrates destabilize the unfolded state of their glycosylated variant compared to the un-glycosylated counterpart [221]. The stability of glycoproteins can be described using the structure of human 
chorionic gonadotropin hormone (hCG) and human CD2, having resolved their various structures using nuclear magnetic resonance, NMR [222-224].

The reports of Wyss et al. have shown the extent of mobility of protein backbone of CD2 and N-acetyl groups of first two GlcNAc residues in CD2. The motion of the amide nitrogen within the glycosylated sites are highly restricted. Residues around the glycosylation site also express considerable rigidity. Similarly, the $\mathrm{N}$-acetyl group of GlcNAc1 is severely restricted compared with mobility of other amide nitrogens in the rigid polypeptide backbone. The study suggested that carbohydrate is essential to stabilize the region around the glycosylation site of CD2. hCG contains 92 amino acid residues with $\alpha$ subunit in the $\alpha \beta$ heterodimeric protein and glycosylated at Asn52 and Asn78. De Beer et al. NMR studies on free $\alpha$-subunit of $\mathrm{hCG}$ and the influence of the $\beta$ subunit on conformation and $\mathrm{N}$-glycosylation of the $\alpha$ subunit indicated that Asn52 glycosylation site on the glycoprotein appears to implicate signal transduction and heterodimer association. Their studies further indicated that carbohydrate at the Asn 78 plays critical roles in maintaining structure of the $\alpha$-subunit. Aside from the critical stability role Asn78, no direct biological activity's role was observed, however, mutant lacking the Asn78 amino acid unit is poorly secreted and degraded rapidly in vivo [225]. Generally, carbohydrates contribute exclusively to entropic terms, while hydrophobic contacts established made between peptide residues contribute to enthalpic energy. Critical observation of the stability of glycoproteins in most cases, attributes their stability due to large entropic effects rather than enthalpy effects [220].

\section{Regulation of glycoproteins in DM}

\section{Chemical compounds}

Glycoproteins are groups of macromolecules that carry out several biological functions including hemoglobin binding, lipids and vitamins transport, as hormone receptors in signal transduction, in assigning immunological specificity and blood coagulation. Abnormalities of glycoprotein metabolism are usually observed both naturally and experimental diabetes, thus some investigations were carried out to study the effect of chemical drugs on plasma and tissue glycoproteins in diabetic rats.

\section{$\mathrm{N}$-benzoyl-D-phenylalanine and metformin}

In non-insulin dependent diabetes mellitus, the potential effects of N-benzoyl-D-phenylalanine and metformin were recognized on the glycoprotein components and glucose metabolism in neonatal streptozotocin-induced experimental diabetic rats. After oral treatment with N-benzoyl-Dphenylalanine and metformin, the hexose, hexosamine, fucose levels were near to normal compared to the diabetic control rats and plasma insulin and tissue sialic acid were increased [226].

\section{2-allyl amino 4-methyl sulfanyl butyric acid}

The 2-allyl amino 4-methyl sulfanyl butyric acid was proposed as a potent antidiabetic agent and also has a protective effect on glycoprotein metabolism. In a study, molecular modeling was used for investigating the modes of 2-allyl amino 4-methyl sulfanyl butyric acid interaction with active sites of insulin receptor. It was found that administration of 2-allyl amino 4-methyl sulfanyl butyric acid (170 $\mathrm{mg} \mathrm{kg}^{-1}$ ) significantly decreased the glycoprotein levels of plasma, liver, and kidney whereas levels of plasma insulin, hexokinase, glycogen and glycogen synthase were potently increased [227].

\section{Succinic acid monoethyl ester}

Pari and Saravanan reported that Succinic acid monoethyl ester has the effective performance on regulation of glycoprotein levels. They experiment on 42 rats (6 control rats, and 36 surviving diabetic rats), Succinic acid monoethyl ester ( 8 $\mu \mathrm{mol} / \mathrm{g}$ bw) was administered intraperitoneally to rats. At the end of the 30 days experimental period, the levels of plasma glycoproteins, glucose and glycosylated were reduced but plasma insulin, tissue sialic acid, and haemoglobin were increased whereas tissue hexose, hexosamine and fucose were near- normal levels [228].

\section{Zinc}

Many trace elements have key roles in glucose metabolism such as Zinc. This vital element is required for various cellular functions, and the major function of Zinc in human metabolism is as a cofactor for different enzymes. In diabetes mellitus, Zinc plays an important role in the storage pancreatic hormone and the stabilization of insulin hexamers. In 2016, Sacan et al. investigated the protective effect of Zinc on the antioxidant enzyme activities and amount of glycoprotein components in lung tissue of diabetic rats [229].

\section{Natural products}

Medicinal plants have been used as one of the most important drug sources all over the world for centuries. There are some studies available which deal with natural products in modifying altered glycoprotein and treating diabetes mellitus that is discussed in following sections (table 1)[230]. 
Table 1 Beneficial effect of Natural products on diabetic rats

\begin{tabular}{|c|c|c|c|}
\hline Phytochemical \& plant name & Compound name & Mechanism of action & References \\
\hline Cardiospermum halicacabum & - & $\begin{array}{l}\downarrow \text { glycoproteins in plasma, liver and kidney } \\
\downarrow \text { glucose levels in the plasma }\end{array}$ & [231] \\
\hline Casearia esculenta & 3-hydroxymethyl xylitol & $\downarrow$ glycoproteins in plasma and tissue & [232] \\
\hline- & $\beta$-caryophyllene & $\begin{array}{l}\text { ameliorates deranged glycoprotein } \\
\downarrow \text { blood glucose } \\
\uparrow \text { plasma insulin }\end{array}$ & [233] \\
\hline Helicteres isora & - & $\downarrow$ glycoproteins in plasma, liver and kidney & [234] \\
\hline- & Tyrosol [4-(2-hydroxyethyl) phenol] & $\begin{array}{l}\downarrow \text { glycoproteins in plasma, liver and kidney } \\
\downarrow \text { blood glucose } \\
\uparrow \text { plasma insulin }\end{array}$ & [235] \\
\hline $\begin{array}{l}\text { Curcuma long } \\
\text { (Zingiberaceae) }\end{array}$ & Tetrahydrocurcumin & $\begin{array}{l}\downarrow \text { glycoproteins in plasma, liver and kidney } \\
\downarrow \text { blood glucose } \\
\uparrow \text { plasma insulin }\end{array}$ & [239] \\
\hline Casearia esculenta & - & $\downarrow$ glycoproteins in plasma, liver, kidney and cardiac tissues & [237] \\
\hline Gymnema montanum & - & $\begin{array}{l}\downarrow \text { glycoproteins in plasma, liver and kidney } \\
\downarrow \text { blood glucose } \\
\uparrow \text { plasma insulin }\end{array}$ & [236] \\
\hline Tephrosia purpurea & - & $\begin{array}{l}\downarrow \text { glycoproteins in plasma, liver and kidney } \\
\downarrow \text { blood glucose } \\
\uparrow \text { plasma insulin }\end{array}$ & [238] \\
\hline- & Umbelliferone (7-hydroxycoumarin) & $\begin{array}{l}\downarrow \text { glycoproteins in plasma and tissues (liver, kidney,heart, and } \\
\quad \text { brain) } \\
\downarrow \text { blood glucose } \\
\uparrow \text { plasma insulin }\end{array}$ & {$[241]$} \\
\hline- & $\begin{array}{l}\text { tetrahydrocurcumin and chlorogenic } \\
\text { acid }\end{array}$ & $\begin{array}{l}\downarrow \text { glycoproteins in plasma, liver and kidney } \\
\downarrow \text { blood glucose } \\
\uparrow \text { plasma insulin }\end{array}$ & {$[240]$} \\
\hline cherry sticks & - & $\begin{array}{l}\downarrow \text { glycoproteins in plasma } \\
\downarrow \text { blood glucose, glycosylated hemoglobin, urea, and creatinine }\end{array}$ & {$[242]$} \\
\hline Vitex negundo & iridoid glucoside & $\begin{array}{l}\downarrow \text { glycoproteins in plasma, liver and kidney } \\
\downarrow \text { blood glucose } \\
\uparrow \text { plasma insulin }\end{array}$ & {$[243]$} \\
\hline Terminalia belerica & - & $\begin{array}{l}\downarrow \text { glycoproteins in plasma } \\
\downarrow \text { blood glucose, glycosylated hemoglobin }\end{array}$ & {$[244]$} \\
\hline Terminalia chebula & & $\begin{array}{l}\downarrow \text { glycoproteins in plasma, liver and kidney } \\
\downarrow \text { blood glucose, glycosylated hemoglobin, urea, and creatinine } \\
\uparrow \text { plasma insulin and C-peptide }\end{array}$ & {$[245]$} \\
\hline- & S-allylcysteine & $\begin{array}{l}\downarrow \text { glycoproteins in plasma, liver and kidney } \\
\downarrow \text { blood glucose } \\
\uparrow \text { plasma insulin }\end{array}$ & {$[246]$} \\
\hline Chard (Beta vulgaris) & - & $\downarrow$ Lung tissue glycoproteins & {$[247]$} \\
\hline
\end{tabular}

\section{Cardiospermum halicacabum}

Considerable attention has recently been paid to the role of various traditionally effective medicinal plants for their efficacy against abnormal glycoprotein levels in diabetes. One of these remedies is Cardiospermum halicacabum leaf, which has been used in Chinese medicine. In this study, Veeramani et al. investigated the protective effect of Cardiospermum halicacabum leaf extract (CHE) on plasma and tissue glycoproteins metabolism of male albino Wistar rats. The animals were made diabetic by an intraperitoneal injection of streptozotocin, then rats were divided into five groups of six rats each: Group I: Normal, Group II: Normal + CHE, Group III: Diabetic control rats, Group IV: Diabetic + CHE, Group V:
Diabetic + glibenclamide. Diabetic rats exhibited an elevated level of blood glucose and treatment with CHE and glibenclamide showed a decreased level of blood glucose. This investigation also indicates that oral administration of Cardiospermum halicacabum leaf extract for 45 days significantly decreased plasma and tissue glycoproteins due to improved glycemic control [231].

\section{3-hydroxymethyl xylitol}

The study of Govindasamy et al was carried out to evaluate the protective role of 3-hydroxymethyl xylitol on glycoprotein metabolism in diabetic rats. Casearia esculenta root has been used therapeutically in India and its extract contains an active 
Fig. 3 The natural products that regulate of glycoproteins for the management of DM

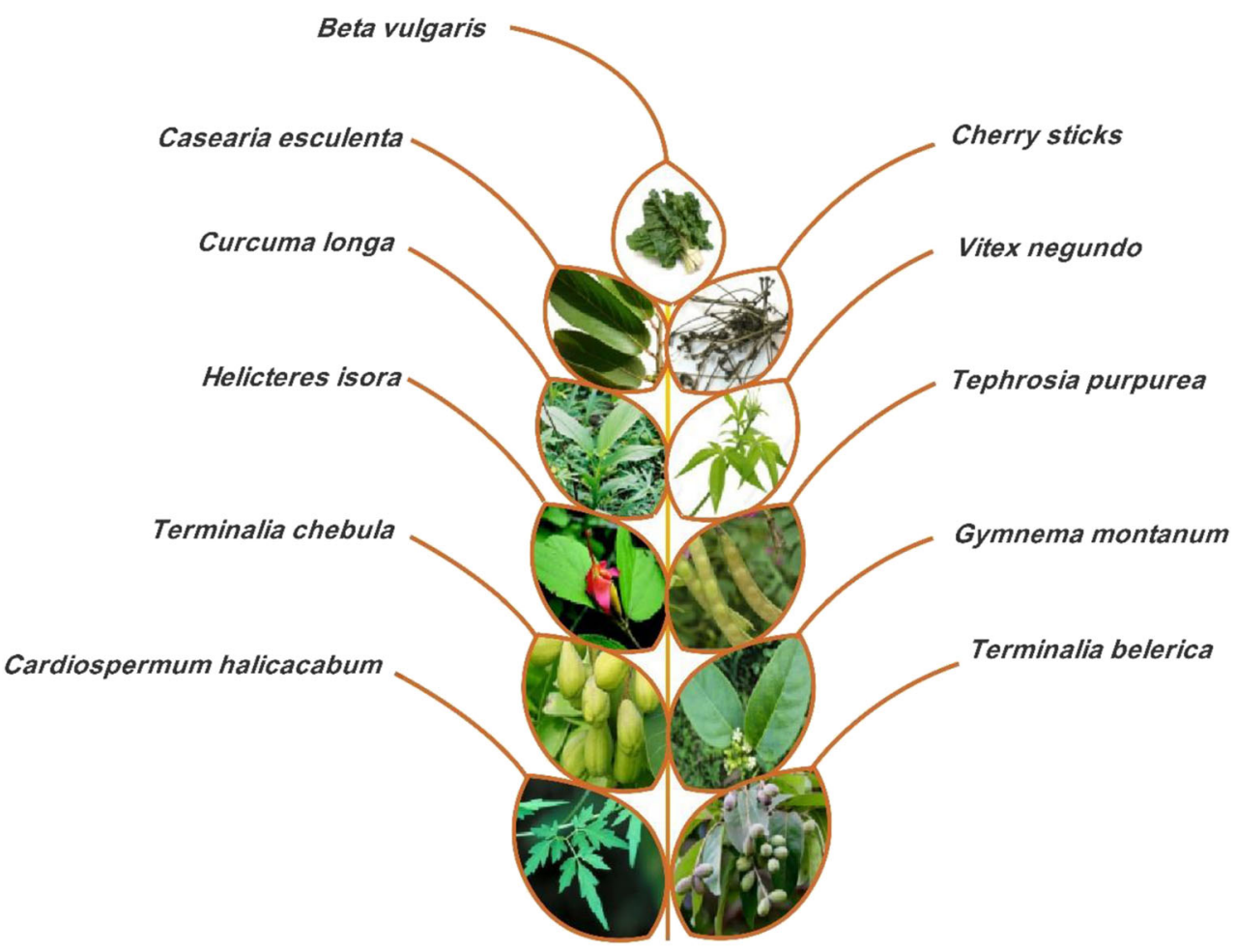

compound 3-hydroxymethyl xylitol. Diabetes was established by injection streptozotocin in rats after then the glycoproteins level containing hexose, hexosamine and fucose in the liver and kidney were significantly increased, and level of sialic

acid elevated except kidney in STZ-induced diabetic rats. The results showed that oral administration of 3 hydroxymethyl xylitol reversed those parameters level toward normal level compared to the untreated diabetic rats [232].

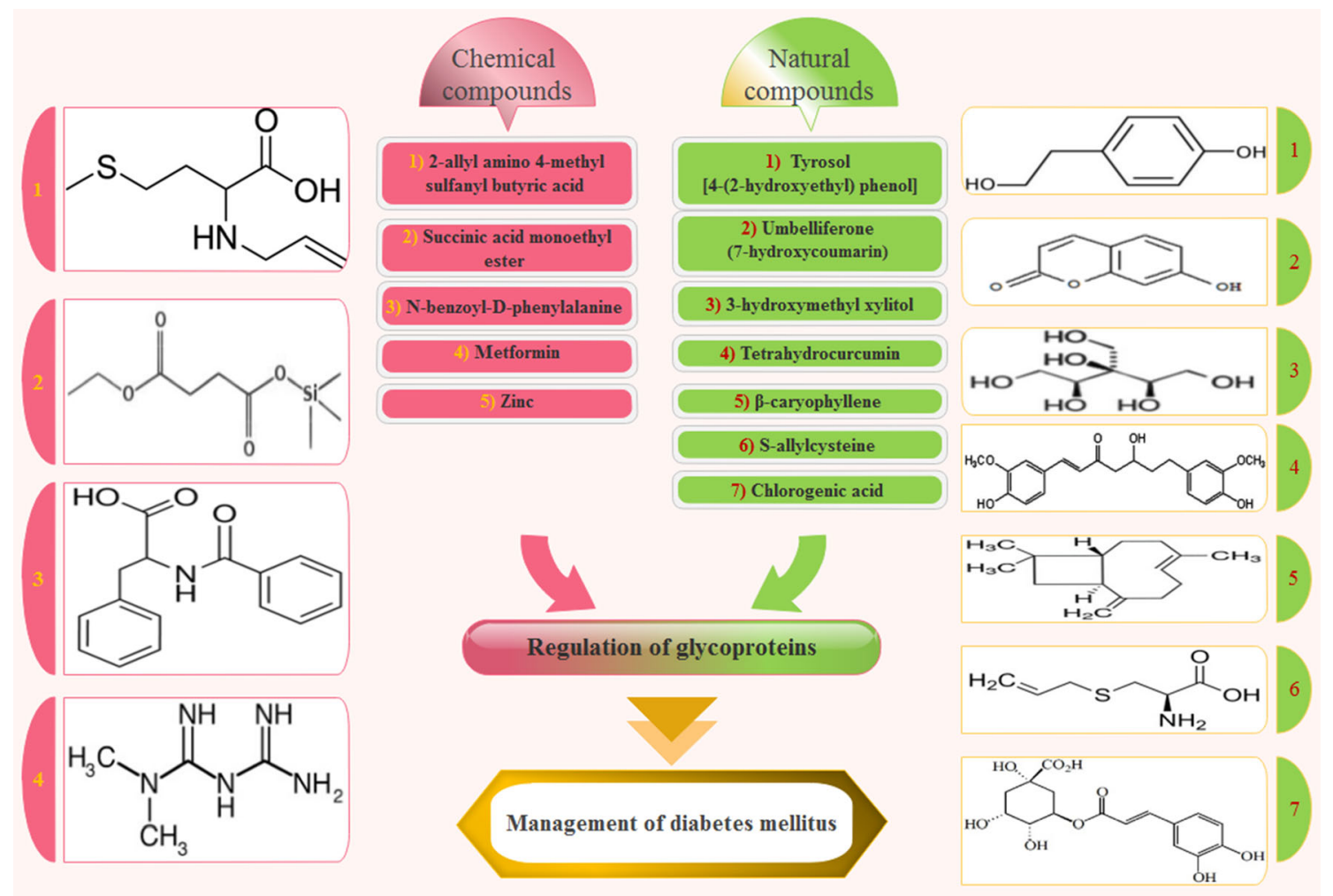

Fig. 4 The structure of natural and chemical compounds that regulate of glycoproteins in DM 


\section{$\beta$-caryophyllene}

$\beta$-caryophyllene is a sesquiterpene lactone compound and mainly present in oil of several Chinese and Indian spices such as thyme, cloves, oregano, black pepper, and cinnamon. In the experimental study, $\beta$-caryophyllene was administered orally ( $200 \mathrm{mg} / \mathrm{kg}$ body weight) for 45 days to diabetic rats and effects were comparable to those with glibenclamide (600 $\mu \mathrm{g} / \mathrm{kg}$ b.w). The results showed $\beta$-caryophyllene in an animal model has revealed significantly decreased blood glucose and increased plasma insulin. The increment in insulin action and secretion will meliorate the metabolism of glycoprotein components in the diabetic state [233].

\section{Helicteres isora}

Another research showed that Helicteres isora plant extract is responsible for the antidiabetic activity and presents a protective performance on the carbohydrate moieties of glycoprotein in STZ induced diabetic rats. The effects of oral administration of Helicteres isora plant extract to diabetic rats directed reduced levels of plasma glycoproteins. The levels of tissue hexosamine, hexose and fucose were reversed to near normal and level of tissue sialic acid has risen. Therefore Helicteres isora plant extract possesses a major protective influence on glycoprotein metabolism in and to lead anti-diabetic effect [234].

\section{Tyrosol [4-(2-hydroxyethyl) phenol]}

The effectiveness of vegetable oils such as olive oil, which has antioxidant agents, is known to improve chronic diseases. Among the natural phenolic compound in olive oil is Tyrosol [4-(2-hydroxyethyl) phenol], which is suggested to be used for the treatment of diabetes mellitus. Chandramohan et al. studied the tyrosol effects on altered components of glycoprotein in diabetic rats. The data showed normalization and restoration of biochemical parameters such as plasma glucose, insulin also significantly decreased hexose, hexosamine, fucose and increased the concentration of sialic acid in the liver and kidney in STZ diabetic rats after oral administration of tyrosol [235].

\section{Gymnema montanum}

Gymnema montanum have been used for pharmacological effect, such as diabetes treatment, as a digestive stimulant, and a diuretic. The antidiabetic potential of leaves extract (ethanolic) of Gymnema montanum was determined in alloxan-induced diabetic rats. It was observed that the leaves extract at $200 \mathrm{mg} / \mathrm{kg}$, enhanced body weight of diabetic rats. Additionally, there was a decrease in blood glucose and an increase in plasma insulin of diabetic rats. Treatment with
Gymnema montanum was successful in reduces glycoprotein components in experimental diabetes [236].

\section{Casearia esculenta}

Casearia esculenta or Wild cowrie fruit is a plant used in traditional medicines in India and is considered as an effective herb against diabetes mellitus. In a study, the extract of Casearia esculenta root was used to decrease glycoprotein in plasma and tissue of STZ diabetic rats. In groups treated with extract of the root $(200,300 \mathrm{mg} / \mathrm{kg})$, it was shown that there was a normalizing effect on glycoprotein components such as hexosamine, hexoses, sialic acid and fucose in plasma, kidney, liver and cardiac tissues [237].

\section{Tephrosia purpurea}

Pavana et al. have reported, the effect of ethanolic extract of Tephrosia purpurea seeds on glycoprotein metabolism in Wistar rats. Animal were categorized into control and experimental groups. In experimental animals, oral treatment with Tephrosia purpurea seeds $(300 \mathrm{mg} / \mathrm{kg}$ ) showed modifying altered glycoprotein components [238].

\section{Tetrahydrocurcumin}

Tetrahydrocurcumin is a common metabolite of curcumin, which has been reported to protect against atherosclerotic lesions, inflammation and hepatotoxicity. A study was conducted a period of 45 days, in which Tetrahydrocurcumin was given at $80 \mathrm{mg} / \mathrm{kg}$ dose in STZ-nicotinamide induced diabetic rats. It was found that Tetrahydrocurcumin administration significantly decreased the plasma glycoproteins and blood glucose [239]. In another study designed to test the effectiveness of tetrahydrocurcumin and chlorogenic acid as a treatment for diabetic rats. These phenolic natural products as individual and combined doses were administered for 45 days to diabetic rats. The results of the investigations show that combined tetrahydrocurcumin and chlorogenic acid treatment provide more effective than individual treating in decreasing glycoproteins, plasma glucose and increased levels of insulin [240].

\section{Umbelliferone (7-hydroxycoumarin)}

Umbelliferone (7-hydroxycoumarin) is a benzopyrone derived from coumarin that is found in fruits. In a study, STZinduced diabetic rats were administered with Umbelliferone dissolved in $10 \%$ dimethyl sulfoxide. It was observed that rats receiving Umbelliferone had decreased glycoprotein levels in the plasma and tissues (brain, heart, liver, and kidney). There was also an increase in insulin plasma and normalization of blood glucose after treatment. [241]. 
Cherry

Cherry is one of the best fruits for many inflammatory diseases. The protective effect of cherry sticks extract on glycoprotein metabolism in diabetic mice was investigated. Administration of cherry sticks extract to diabetic mice indicates the metabolic alteration of glycoprotein reverted towards normal levels [242].

\section{iridoid glucoside}

Sundaram et al. described an experimental diabetic model in male albino Wistar rats by administering STZ. The isolated iridoid glucoside from the leaves of Vitex negundo was administered orally to STZ-diabetic rats for 30 days. The effects of iridoid glucoside were compared to glibenclamide, which is often used as a standard drug. After administration of iridoid glucoside to diabetic rats, the metabolic alteration of glycoproteins in plasma, liver, and kidney reverted towards normal levels [243].

\section{Terminalia}

Some researchers have suggested the effects of fruits extract such as Terminalia belerica [244], Terminalia chebula [245] on the levels of plasma and tissue glycoprotein components in diabetic rats and results showed diabetic rats had decreased plasma insulin and elevated blood glucose, sialic acid, total hexoses, fucose, and hexosamines in the plasma and tissues.

\section{S-allylcysteine}

S-allylcysteine is a sulfur containing amino acid, a derivative of garlic, treatment with S-allylcysteine has developed glycemic control and therewith reduced the formation of glycoprotein components in addition to its antioxidant activity effect [246].

\section{Chard (Beta vulgaris)}

Many researches have been conducted that decrease in hyperglycemia could lead to a reduction in glycoprotein components. Research by Sacan et al. has shown the effect of Chard (Beta vulgaris), is a green leafy vegetable, on lungs glycoprotein components. In this study insulin, chard and chard insulin administration resulted in reversal of glycoprotein components in the lungs of diabetic rats except for hexose values. So chard indicates protective features against diabetic complications, as evidenced by normalization of glycoprotein components and well glycemic control [247]. The natural products and chemical compounds are shown in Fig. 3 and 4.

\section{Conclusion}

A large number of proteins that exist in nature are covalently linked to carbohydrates forming glycoprotein. They are vital form of biomolecules that partake in numerous type of physiological and abnormal conditions. These proteincarbohydrate compounds exist in many forms of vital importance, such as hormones, enzymes, membranes, antibodies among others. The comprehension of their structure and functions are very essential and inevitable to enhance the knowledge of glycoengineering for glycoprotein-based therapeutics as may be required for treatment of diabetes mellitus and its associated complications. Abnormalities of glycoprotein metabolism are generally founded in the diabetic state. Based on reviewed animal studies, different traditional medicaments and chemical compounds are potentially efficacious on regulation of glycoproteins in diabetes mellitus.

Author Contributions RN, MHF designed the paper. MHF, SJN \& ZS collected the literature data, and RN, ZS. APM, MN, AO, HT \& RPM wrote the paper. SJN \& APM improved the final version. All authors participated in the analysis and interpretation of literature data, revised the paper and approved the final manuscript.

Funding This study was not supported by any funding.

\section{Compliance with ethical standards}

Conflict of Interest The authors declare that they have no conflict of interest.

Ethical approval This article does not contain any studies with human participants or animals performed by any of the authors.

\section{References}

1. World Health O. Global report on diabetes. Geneva: World Health Organization; 2016. https://apps.who.int/iris/handle/10665/204871

2. Emerging Risk Factors C, Sarwar N, Gao P, Seshasai SR, Gobin $\mathrm{R}$, Kaptoge S, et al. Diabetes mellitus, fasting blood glucose concentration, and risk of vascular disease: a collaborative metaanalysis of 102 prospective studies. Lancet. 2010;375(9733): 2215-22. https://doi.org/10.1016/S0140-6736(10)60484-9.

3. Kaiser AB, Zhang N, Der Pluijm WV. Global Prevalence of Type 2 Diabetes over the Next Ten Years (2018-2028). Diabetes. 2018;67(Supplement 1):202-LB. https://oi.org/10.2337/db18-202LB.

4. Spiro RG. Glycoproteins: Their biochemistry, biology and role in human disease. N Engl J Med. 1969;281(19):1043-56. https:// doi.org/10.1056/nejm196911062811905.

5. Varki A. Biological roles of glycans. Glycobiology. 2017;27(1):349. https://doi.org/10.1093/glycob/cww086.

6. Petrescu AJ, Wormald MR, Dwek RA. Structural aspects of glycomes with a focus on N-glycosylation and glycoprotein folding. Curr Opin Struct Biol. 2006;16(5):600-7. https://doi.org/10. 1016/j.sbi.2006.08.007. 
7. Haltiwanger RS, Lowe JB. Role of glycosylation in development. Annu Rev Biochem. 2004;73(1):491-537. https://doi.org/10. 1146/annurev.biochem.73.011303.074043.

8. Hart GW, Copeland RJ. Glycomics hits the big time. Cell. 2010;143(5):672-6. https://doi.org/10.1016/j.cell.2010.11.008.

9. Slawson C, Hart GW. O-GlcNAc signalling: implications for cancer cell biology. Nat Rev Cancer. 2011;11(9):678-84. https://doi. org/10.1038/nrc3114.

10. Helenius A, Aebi M. Intracellular functions of N-linked glycans. Science. 2001;291(5512):2364-9.

11. Roth J, Zuber C. Quality control of glycoprotein folding and ERAD: the role of N-glycan handling, EDEM1 and OS-9. Histochem Cell Biol. 2017;147(2):269-84. https://doi.org/10. 1007/s00418-016-1513-9.

12. Gary-Bobo M, Nirde P, Jeanjean A, Morere A, Garcia M. Mannose 6-phosphate receptor targeting and its applications in human diseases. Curr Med Chem. 2007;14(28):2945-53.

13. Coutinho MF, Prata MJ, Alves S. Mannose-6-phosphate pathway: a review on its role in lysosomal function and dysfunction. Mol Genet Metab. 2012;105(4):542-50. https://doi.org/10.1016/j. ymgme.2011.12.012.

14. Stencel-Baerenwald JE, Reiss K, Reiter DM, Stehle T, Dermody TS. The sweet spot: defining virus-sialic acid interactions. Nat Rev Microbiol. 2014;12(11):739-49. https://doi.org/10.1038/ nrmicro3346.

15. Tytgat HL, Lebeer S. The sweet tooth of bacteria: common themes in bacterial glycoconjugates. Microbiol Mol Biol Rev. 2014;78(3): 372-417. https://doi.org/10.1128/mmbr.00007-14

16. Valguarnera E, Kinsella RL, Feldman MF. Sugar and Spice Make Bacteria Not Nice: Protein Glycosylation and Its Influence in Pathogenesis. J Mol Biol. 2016;428(16):3206-20. https://doi. org/10.1016/j.jmb.2016.04.013.

17. Tytgat HLP, de Vos WM. Sugar Coating the Envelope: Glycoconjugates for Microbe-Host Crosstalk. Trends Microbiol. 2016;24(11):853-61. https://doi.org/10.1016/j.tim.2016.06.004.

18. Raman R, Tharakaraman K, Sasisekharan V, Sasisekharan R. Glycan-protein interactions in viral pathogenesis. Curr Opin Struct Biol. 2016;40:153-62. https://doi.org/10.1016/j.sbi.2016. 10.003 .

19. Dube DH, Bertozzi CR. Glycans in cancer and inflammationpotential for therapeutics and diagnostics. Nat Rev Drug Discov. 2005;4(6):477-88. https://doi.org/10.1038/nrd1751.

20. Zhao J, Patwa TH, Lubman DM, Simeone DM. Protein biomarkers in cancer: natural glycoprotein microarray approaches. Curr Opin Mol Ther. 2008;10(6):602-10.

21. Reis CA, Osorio H, Silva L, Gomes C, David L. Alterations in glycosylation as biomarkers for cancer detection. J Clin Pathol. 2010;63(4):322-9. https://doi.org/10.1136/jcp.2009.071035.

22. Jefferis R. Glycosylation as a strategy to improve antibody-based therapeutics. Nat Rev Drug Discov. 2009;8(3):226-34. https://doi. org $/ 10.1038 / \mathrm{nrd} 2804$.

23. Walsh G, Jefferis R. Post-translational modifications in the context of therapeutic proteins. Nat Biotechnol. 2006;24(10):1241-52. https://doi.org/10.1038/nbt1252.

24. Siddiqui AA, Siddiqui SA, Ahmad S, Siddiqui S, Ahsan I, Sahu K. Diabetes: Mechanism, pathophysiology and management-A review. Int J Drug Dev Res. 2013;5(2):1-23.

25. Maahs DM, West NA, Lawrence JM, Mayer-Davis EJ. Epidemiology of type 1 diabetes. Endocrinol Metab Clin N Am. 2010;39(3):481-97. https://doi.org/10.1016/j.ecl.2010.05.011.

26. Livingstone SJ, Levin D, Looker HC, Lindsay RS, Wild SH, Joss $\mathrm{N}$, et al. Estimated life expectancy in a Scottish cohort with type 1 diabetes, 2008-2010. Jama. 2015;313(1):37-44. https://doi.org/ 10.1001/jama.2014.16425.

27. Redondo MJ, Rewers M, Yu L, Garg S, Pilcher CC, Elliott RB, et al. Genetic determination of islet cell autoimmunity in monozygotic twin, dizygotic twin, and non-twin siblings of patients with type 1 diabetes: prospective twin study. BMJ (Clinical Research ed). 1999;318(7185):698-702.

28. Beyan H, Riese H, Hawa MI, Beretta G, Davidson HW, Hutton JC, et al. Glycotoxin and autoantibodies are additive environmentally determined predictors of type 1 diabetes: a twin and population study. Diabetes. 2012;61(5):1192-8. https://doi.org/10.2337/ db11-0971.

29. Skyler JS, Bakris GL, Bonifacio E, Darsow T, Eckel RH, Groop L, et al. Differentiation of Diabetes by Pathophysiology, Natural History, and Prognosis. Diabetes. 2017;66(2):241-55. https://doi. org/10.2337/db16-0806.

30. Hamalainen AM, Knip M. Autoimmunity and familial risk of type 1 diabetes. Curr Diab Rep. 2002;2(4):347-53. https://doi.org/10. 1007/s11892-002-0025-2

31. Storling J, Pociot F. Type 1 diabetes candidate genes linked to pancreatic islet cell inflammation and beta-cell apoptosis. Genes. 2017;8(2). https://doi.org/10.3390/genes8020072.

32. Noble JA, Valdes AM, Varney MD, Carlson JA, Moonsamy P, Fear AL, et al. HLA class I and genetic susceptibility to type 1 diabetes: results from the Type 1 Diabetes Genetics Consortium. Diabetes. 2010;59(11):2972-9. https://doi.org/10.2337/db100699.

33. Hu C, Wong FS, Wen L. Type 1 diabetes and gut microbiota: Friend or foe? Pharmacol Res. 2015;98:9-15. https://doi.org/10. 1016/j.phrs.2015.02.006.

34. Hu X, Deutsch AJ, Lenz TL, Onengut-Gumuscu S, Han B, Chen $\mathrm{WM}$, et al. Additive and interaction effects at three amino acid positions in HLA-DQ and HLA-DR molecules drive type 1 diabetes risk. Nat Genet. 2015;47(8):898-905. https://doi.org/10. 1038/ng.3353.

35. Rich SS. Mapping genes in diabetes. Genetic epidemiological perspective. Diabetes. 1990;39(11):1315-9.

36. Atkinson MA. The pathogenesis and natural history of type 1 diabetes. Cold Spring Harbor perspectives in medicine. 2012;2(11). https://doi.org/10.1101/cshperspect.a007641.

37. Paschou SA, Papadopoulou-Marketou N, Chrousos GP, KanakaGantenbein C. On type 1 diabetes mellitus pathogenesis. Endocr Connect. 2018;7(1):R38-46. https://doi.org/10.1530/EC-170347.

38. Jerram ST, Dang MN, Leslie RD. The Role of Epigenetics in Type 1 Diabetes. Curr Diab Rep. 2017;17(10):89. https://doi.org/10. 1007/s11892-017-0916-x .

39. Rakyan VK, Beyan H, Down TA, Hawa MI, Maslau S, Aden D, et al. Identification of type 1 diabetes-associated DNA methylation variable positions that precede disease diagnosis. PLoS Genet. 2011;7(9):e1002300.

40. Stefan M, Zhang W, Concepcion E, Yi Z, Tomer Y. DNA methylation profiles in type 1 diabetes twins point to strong epigenetic effects on etiology. J Autoimmun. 2014;50:33-7. https://doi.org/ 10.1016/j.jaut.2013.10.001.

41. Olsson AH, Volkov P, Bacos K, Dayeh T, Hall E, Nilsson EA, et al. Genome-wide associations between genetic and epigenetic variation influence mRNA expression and insulin secretion in human pancreatic islets. PLoS Genet. 2014;10(11):e1004735. https://doi.org/10.1371/journal.pgen.1004735.

42. Farh KK, Marson A, Zhu J, Kleinewietfeld M, Housley WJ, Beik $\mathrm{S}$, et al. Genetic and epigenetic fine mapping of causal autoimmune disease variants. Nature. 2015;518(7539):337-43. https:// doi.org/10.1038/nature13835.

43. Rui J, Deng S, Lebastchi J, Clark PL, Usmani-Brown S, Herold KC. Methylation of insulin DNA in response to proinflammatory cytokines during the progression of autoimmune diabetes in NOD mice. Diabetologia. 2016;59(5):1021-9. https://doi.org/10.1007/ s00125-016-3897-4. 
44. Paul DS, Teschendorff AE, Dang MA, Lowe R, Hawa MI, Ecker $\mathrm{S}$, et al. Increased DNA methylation variability in type 1 diabetes across three immune effector cell types. Nat Commun. 2016;7: 13555. https://doi.org/10.1038/ncomms13555.

45. Khan F, Momtaz S, Niaz K, Hassan FI, Abdollahi M. Epigenetic mechanisms underlying the toxic effects associated with arsenic exposure and the development of diabetes. Food Chem Toxicol. 2017;107(Pt A):406-17. https://doi.org/10.1016/j.fct.2017.07. 021

46. van Belle TL, Coppieters KT, von Herrath MG. Type 1 diabetes: etiology, immunology, and therapeutic strategies. Physiol Rev. 2011;91(1):79-118. https://doi.org/10.1152/physrev.00003.2010.

47. Hober D, Sauter P. Pathogenesis of type 1 diabetes mellitus: interplay between enterovirus and host. Nat Rev Endocrinol. 2010;6(5):279-89. https://doi.org/10.1038/nrendo.2010.27.

48. Hober D, Alidjinou EK. Enteroviral pathogenesis of type 1 diabetes: queries and answers. Curr Opin Infect Dis. 2013;26(3):263-9. https://doi.org/10.1097/QCO.0b013e3283608300.

49. Dotta F, Censini S, van Halteren AG, Marselli L, Masini M, Dionisi S, et al. Coxsackie B4 virus infection of beta cells and natural killer cell insulitis in recent-onset type 1 diabetic patients. Proc Natl Acad Sci U S A. 2007;104(12):5115-20. https://doi.org/ 10.1073/pnas.0700442104.

50. Virtanen SM, Saukkonen T, Savilahti E, Ylonen K, Rasanen L, Aro A, et al. Diet, cow's milk protein antibodies and the risk of IDDM in Finnish children. Childhood Diabetes in Finland Study Group. Diabetologia. 1994;37(4):381-7.

51. Karlsson MG, Ludvigsson J. The ABBOS-peptide from bovine serum albumin causes an IFN-gamma and IL-4 mRNA response in lymphocytes from children with recent onset of type 1 diabetes. Diabetes Res Clin Pract. 2000;47(3):199-207.

52. Norris JM, Barriga K, Klingensmith G, Hoffman M, Eisenbarth GS, Erlich HA, et al. Timing of initial cereal exposure in infancy and risk of islet autoimmunity. Jama. 2003;290(13):1713-20. https://doi.org/10.1001/jama.290.13.1713.

53. Ziegler AG, Schmid S, Huber D, Hummel M, Bonifacio E. Early infant feeding and risk of developing type 1 diabetes-associated autoantibodies. Jama. 2003;290(13):1721-8. https://doi.org/10. 1001/jama.290.13.1721.

54. Norris JM, Yin X, Lamb MM, Barriga K, Seifert J, Hoffman M, et al. Omega- 3 polyunsaturated fatty acid intake and islet autoimmunity in children at increased risk for type 1 diabetes. Jama. 2007;298(12):1420-8. https://doi.org/10.1001/jama.298.12.1420.

55. Parslow RC, McKinney PA, Law GR, Staines A, Williams R, Bodansky HJ. Incidence of childhood diabetes mellitus in Yorkshire, northern England, is associated with nitrate in drinking water: an ecological analysis. Diabetologia. 1997;40(5):550-6. https://doi.org/10.1007/s001250050714.

56. Kostraba JN, Gay EC, Rewers M, Hamman RF. Nitrate levels in community drinking waters and risk of IDDM. An ecological analysis. Diabetes Care. 1992;15(11):1505-8.

57. Halipchuk J, Temple B, Dart A, Martin D, Sellers EAC. Prenatal, Obstetric and Perinatal Factors Associated With the Development of Childhood-Onset Type 2 Diabetes. Can J Diabetes. 2018;42(1): 71-7. https://doi.org/10.1016/j.jcjd.2017.04.003.

58. McKinney PA, Parslow R, Gurney K, Law G, Bodansky HJ, Williams DR. Antenatal risk factors for childhood diabetes mellitus; a case-control study of medical record data in Yorkshir, UK. Diabetologia. 1997;40(8):933-9. https://doi.org/10.1007/ s001250050770

59. Patterson CC, Carson DJ, Hadden DR, Waugh NR, Cole SK. A case-control investigation of perinatal risk factors for childhood IDDM in Northern Ireland and Scotland. Diabetes Care. 1994;17(5):376-81. https://doi.org/10.2337/diacare.17.5.376
60. Flood TM, Brink SJ, Gleason RE. Increased incidence of type I diabetes in children of older mothers. Diabetes Care. 1982;5(6): 571-3. https://doi.org/10.2337/diacare.5.6.571

61. Liao XP, Yu Y, Marc I, Dubois L, Abdelouahab N, Bouchard L, et al. Prenatal determinants of childhood obesity: a review of risk factors (1). Can J Physiol Pharmacol. 2019;97(3):147-54. https:// doi.org/10.1139/cjpp-2018-0403.

62. Giongo A, Gano KA, Crabb DB, Mukherjee N, Novelo LL, Casella G, et al. Toward defining the autoimmune microbiome for type 1 diabetes. The ISME journal. 2011;5(1):82-91. https:// doi.org/10.1038/ismej.2010.92.

63. Vaarala O, Atkinson MA, Neu J. The "perfect storm" for type 1 diabetes: the complex interplay between intestinal microbiota, gut permeability, and mucosal immunity. Diabetes. 2008;57(10): 2555-62. https://doi.org/10.2337/db08-0331.

64. Bonifacio E, Warncke K, Winkler C, Wallner M, Ziegler AG. Cesarean section and interferon-induced helicase gene polymorphisms combine to increase childhood type 1 diabetes risk. Diabetes. 2011;60(12):3300-6. https://doi.org/10.2337/db110729.

65. Bottazzo GF, Florin-Christensen A, Doniach D. Islet-cell antibodies in diabetes mellitus with autoimmune polyendocrine deficiencies. Lancet. 1974;2(7892):1279-83.

66. Baekkeskov S, Aanstoot HJ, Christgau S, Reetz A, Solimena M, Cascalho M, et al. Identification of the $64 \mathrm{~K}$ autoantigen in insulindependent diabetes as the GABA-synthesizing enzyme glutamic acid decarboxylase. Nature. 1990;347(6289):151-6. https://doi. org/10.1038/347151a0.

67. Lan MS, Lu J, Goto Y, Notkins AL. Molecular cloning and identification of a receptor-type protein tyrosine phosphatase, IA-2, from human insulinoma. DNA Cell Biol. 1994;13(5):505-14. https://doi.org/10.1089/dna.1994.13.505.

68. Wenzlau JM, Juhl K, Yu L, Moua O, Sarkar SA, Gottlieb P, et al. The cation efflux transporter ZnT8 (Slc30A8) is a major autoantigen in human type 1 diabetes. Proc Natl Acad Sci U S A. 2007;104(43):17040-5. https://doi.org/10.1073/pnas. 0705894104

69. Vehik K, Lynch KF, Schatz DA, Akolkar B, Hagopian W, Rewers $\mathrm{M}$, et al. Reversion of beta-Cell Autoimmunity Changes Risk of Type 1 Diabetes: TEDDY Study. Diabetes Care. 2016;39(9): 1535-42. https://doi.org/10.2337/dc16-0181.

70. Ziegler AG, Rewers M, Simell O, Simell T, Lempainen J, Steck A, et al. Seroconversion to multiple islet autoantibodies and risk of progression to diabetes in children. Jama. 2013;309(23):2473-9. https://doi.org/10.1001/jama.2013.6285.

71. Steck AK, Vehik K, Bonifacio E, Lernmark A, Ziegler AG, Hagopian WA, et al. Predictors of Progression From the Appearance of Islet Autoantibodies to Early Childhood Diabetes: The Environmental Determinants of Diabetes in the Young (TEDDY). Diabetes Care. 2015;38(5):808-13. https:// doi.org/10.2337/dc14-2426.

72. Verge CF, Gianani R, Kawasaki E, Yu L, Pietropaolo M, Jackson RA, et al. Prediction of type I diabetes in first-degree relatives using a combination of insulin, GAD, and ICA512bdc/IA-2 autoantibodies. Diabetes. 1996;45(7):926-33.

73. Krischer JP, Liu X, Lernmark A, Hagopian WA, Rewers MJ, She JX, et al. The Influence of Type 1 Diabetes Genetic Susceptibility Regions, Age, Sex, and Family History on the Progression From Multiple Autoantibodies to Type 1 Diabetes: A TEDDY Study Report. Diabetes. 2017;66(12):3122-9. https://doi.org/10.2337/ db17-0261.

74. Cunha DA, Igoillo-Esteve M, Gurzov EN, Germano CM, Naamane N, Marhfour I, et al. Death protein 5 and p53upregulated modulator of apoptosis mediate the endoplasmic reticulum stress-mitochondrial dialog triggering lipotoxic rodent 
and human beta-cell apoptosis. Diabetes. 2012;61(11):2763-75. https://doi.org/10.2337/db12-0123.

75. Eizirik DL, Colli ML, Ortis F. The role of inflammation in insulitis and beta-cell loss in type 1 diabetes. Nat Rev Endocrinol. 2009;5(4):219-26. https://doi.org/10.1038/nrendo.2009.21.

76. Atkinson MA, Maclaren NK. The pathogenesis of insulindependent diabetes mellitus. N Engl J Med. 1994;331(21):142836. https://doi.org/10.1056/nejm199411243312107.

77. Turunen JA, Wessman M, Forsblom C, Kilpikari R, Parkkonen M, Pontynen N, et al. Association analysis of the AIRE and insulin genes in Finnish type 1 diabetic patients. Immunogenetics. 2006;58(5-6):331-8. https://doi.org/10.1007/s00251-006-0088-3.

78. Jaidane H, Caloone D, Lobert PE, Sane F, Dardenne O, Naquet P, et al. Persistent infection of thymic epithelial cells with coxsackievirus B4 results in decreased expression of type 2 insulin-like growth factor. J Virol. 2012;86(20):11151-62. https://doi.org/10.1128/jvi.00726-12.

79. Hull CM, Peakman M, Tree TIM. Regulatory T cell dysfunction in type 1 diabetes: what's broken and how can we fix it? Diabetologia. 2017;60(10):1839-50. https://doi.org/10.1007/ s00125-017-4377-1.

80. Yaribeygi H, Farrokhi FR, Butler AE, Sahebkar A. Insulin resistance: Review of the underlying molecular mechanisms. J Cell Physiol. 2019;234(6):8152-61. https://doi.org/10.1002/jcp. 27603.

81. Groop L, Forsblom C, Lehtovirta M, Tuomi T, Karanko S, Nissen $\mathrm{M}$, et al. Metabolic consequences of a family history of NIDDM (the Botnia study): evidence for sex-specific parental effects. Diabetes. 1996;45(11):1585-93.

82. Ozougwu J, Obimba K, Belonwu C, Unakalamba C. The pathogenesis and pathophysiology of type 1 and type 2 diabetes mellitus. J Physiol Pathophysiol. 2013;4(4):46-57.

83. Kaprio J, Tuomilehto J, Koskenvuo M, Romanov K, Reunanen A, Eriksson J, et al. Concordance for type 1 (insulin-dependent) and type 2 (non-insulin-dependent) diabetes mellitus in a populationbased cohort of twins in Finland. Diabetologia. 1992;35(11): 1060-7.

84. Cook JT, Hattersley AT, Levy JC, Patel P, Wainscoat JS, Hockaday TD, et al. Distribution of type II diabetes in nuclear families. Diabetes. 1993;42(1):106-12.

85. Zhang ZY, Miao LF, Qian LL, Wang N, Qi MM, Zhang YM, et al. Molecular Mechanisms of Glucose Fluctuations on Diabetic Complications. Front Endocrinol (Lausanne). 2019;10(640):640. https://doi.org/10.3389/fendo.2019.00640.

86. Ali O. Genetics of type 2 diabetes. World J Diabetes. 2013;4(4): 114-23. https://doi.org/10.4239/wjd.v4.i4.114.

87. Vaxillaire M, Froguel P. Monogenic diabetes in the young, pharmacogenetics and relevance to multifactorial forms of type 2 diabetes. Endocr Rev. 2008;29(3):254-64. https://doi.org/10.1210/er. 2007-0024.

88. Hanis CL, Boerwinkle E, Chakraborty R, Ellsworth DL, Concannon P, Stirling B, et al. A genome-wide search for human non-insulin-dependent (type 2) diabetes genes reveals a major susceptibility locus on chromosome 2. Nat Genet. 1996;13(2): 161-6. https://doi.org/10.1038/ng0696-161.

89. Keenan MJ, Zhou J, Hegsted M, Pelkman C, Durham HA, Coulon $\mathrm{DB}$, et al. Role of resistant starch in improving gut health, adiposity, and insulin resistance. Adv Nutr. 2015;6(2):198-205. https:// doi.org/10.3945/an.114.007419.

90. Furuta H, Furuta M, Sanke T, Ekawa K, Hanabusa T, Nishi M, et al. Nonsense and missense mutations in the human hepatocyte nuclear factor-1 beta gene (TCF2) and their relation to type 2 diabetes in Japanese. J Clin Endocrinol Metab. 2002;87(8): 3859-63. https://doi.org/10.1210/jcem.87.8.8776.

91. Ringel J, Engeli S, Distler A, Sharma AM. Pro12Ala missense mutation of the peroxisome proliferator activated receptor gamma and diabetes mellitus. Biochem Biophys Res Commun. 1999;254(2):450-3. https://doi.org/10.1006/bbrc.1998.9962.

92. Hani EH, Boutin P, Durand E, Inoue H, Permutt MA, Velho G, et al. Missense mutations in the pancreatic islet beta cell inwardly rectifying $\mathrm{K}+$ channel gene (KIR6.2/BIR): a meta-analysis suggests a role in the polygenic basis of Type II diabetes mellitus in Caucasians. Diabetologia. 1998;41(12):1511-5. https://doi.org/ $10.1007 / \mathrm{s} 001250051098$.

93. Sandhu MS, Weedon MN, Fawcett KA, Wasson J, Debenham SL, Daly A, et al. Common variants in WFS1 confer risk of type 2 diabetes. Nat Genet. 2007;39(8):951-3. https://doi.org/10.1038/ ng2067.

94. Tong Y, Lin Y, Zhang Y, Yang J, Zhang Y, Liu H, et al. Association between TCF7L2 gene polymorphisms and susceptibility to type 2 diabetes mellitus: a large Human Genome Epidemiology (HuGE) review and meta-analysis. BMC Med Genet. 2009;10: 15. https://doi.org/10.1186/1471-2350-10-15.

95. Duggirala R, Blangero J, Almasy L, Dyer TD, Williams KL, Leach RJ, et al. Linkage of type 2 diabetes mellitus and of age at onset to a genetic location on chromosome 10q in Mexican Americans. Am J Hum Genet. 1999;64(4):1127-40.

96. Karachanak-Yankova S, Dimova R, Nikolova D, Nesheva D, Koprinarova M, Maslyankov S, et al. Epigenetic alterations in patients with type 2 diabetes mellitus. Balkan Journal of Medical Genetics : BJMG. 2015;18(2):15-24. https://doi.org/10.1515/ bjmg-2015-0081.

97. Ling C, Groop L. Epigenetics: a molecular link between environmental factors and type 2 diabetes. Diabetes. 2009;58(12):2718 25. https://doi.org/10.2337/db09-1003.

98. Ling C, Del Guerra S, Lupi R, Ronn T, Granhall C, Luthman H, et al. Epigenetic regulation of PPARGC1A in human type 2 diabetic islets and effect on insulin secretion. Diabetologia. 2008;51(4):615-22. https://doi.org/10.1007/s00125-007-0916-5.

99. Ronn T, Poulsen P, Hansson O, Holmkvist J, Almgren P, Nilsson $\mathrm{P}$, et al. Age influences DNA methylation and gene expression of COX7A1 in human skeletal muscle. Diabetologia. 2008;51(7): 1159-68. https://doi.org/10.1007/s00125-008-1018-8.

100. Krishnamurthy J, Ramsey MR, Ligon KL, Torrice C, Koh A, Bonner-Weir S, et al. p16INK4a induces an age-dependent decline in islet regenerative potential. Nature. 2006;443(7110):453-7. https://doi.org/10.1038/nature05092.

101. Chen H, Gu X, Su IH, Bottino R, Contreras JL, Tarakhovsky A, et al. Polycomb protein Ezh2 regulates pancreatic beta-cell Ink4a/ Arf expression and regeneration in diabetes mellitus. Genes Dev. 2009;23(8):975-85. https://doi.org/10.1101/gad.1742509.

102. Dhawan S, Tschen SI, Bhushan A. Bmi-1 regulates the Ink4a/Arf locus to control pancreatic beta-cell proliferation. Genes Dev. 2009;23(8):906-11. https://doi.org/10.1101/gad.1742609.

103. Sladek R, Rocheleau G, Rung J, Dina C, Shen L, Serre D, et al. A genome-wide association study identifies novel risk loci for type 2 diabetes. Nature. 2007;445(7130):881-5. https://doi.org/10.1038/ nature 05616

104. Haffner SM, Mitchell BD, Stern MP, Hazuda HP, Patterson JK. Public health significance of upper body adiposity for non-insulin dependent diabetes mellitus in Mexican Americans.nt J Obes Relat Metab Disord. 1992;16(3):177-84.

105. Tabatabaei-Malazy O, Nikfar S, Larijani B, Abdollahi M. Drugs for the treatment of pediatric type 2 diabetes mellitus and related co-morbidities. Expert Opin Pharmacother. 2016;17(18):2449-60. https://doi.org/10.1080/14656566.2016.1258057.

106. van der Zijl NJ, Goossens GH, Moors CC, van Raalte DH, Muskiet MH, Pouwels PJ, et al. Ectopic fat storage in the pancreas, liver, and abdominal fat depots: impact on beta-cell function in individuals with impaired glucose metabolism. J Clin Endocrinol Metab. 2011;96(2):459-67. https://doi.org/10.1210/jc.2010-1722. 
107. Fonseca VA, Capehorn MS, Garg SK, Jodar Gimeno E, Hansen $\mathrm{OH}$, Holst AG, et al. Reductions in insulin resistance are mediated primarily via weight loss in subjects with type 2 diabetes on semaglutide. J Clin Endocrinol Metab. 2019. https://doi.org/10. 1210/jc.2018-02685.

108. Lim EL, Hollingsworth KG, Aribisala BS, Chen MJ, Mathers JC, Taylor R. Reversal of type 2 diabetes: normalisation of beta cell function in association with decreased pancreas and liver triacylglycerol. Diabetologia. 2011;54(10):2506-14. https://doi.org/10. 1007/s00125-011-2204-7.

109. Vidal-Puig AJ, Considine RV, Jimenez-Linan M, Werman A, Pories WJ, Caro JF, et al. Peroxisome proliferator-activated receptor gene expression in human tissues. Effects of obesity, weight loss, and regulation by insulin and glucocorticoids. J Clin Invest. 1997;99(10):2416-22. https://doi.org/10.1172/jci119424.

110. Lee DH, Lee IK, Song K, Steffes M, Toscano W, Baker BA, et al. A strong dose-response relation between serum concentrations of persistent organic pollutants and diabetes: results from the National Health and Examination Survey 1999-2002. Diabetes Care. 2006;29(7):1638-44. https://doi.org/10.2337/dc06-0543.

111. Porta M. Persistent organic pollutants and the burden of diabetes. Lancet. 2006;368(9535):558-9. https://doi.org/10.1016/s01406736(06)69174-5.

112. Lee D-H, Jacobs DR Jr, Porta M. Could low-level background exposure to persistent organic pollutants contribute to the social burden of type 2 diabetes? J Epidemiol Community Health. 2006;60(12):1006-8. https://doi.org/10.1136/jech.2006.053389.

113. Murea M, Ma L, Freedman BI. Genetic and environmental factors associated with type 2 diabetes and diabetic vascular complications. Rev Diabet Stud. 2012;9(1):6-22. https://doi.org/10.1900/ rds.2012.9.6

114. Sun Q, Yue P, Deiuliis JA, Lumeng CN, Kampfrath T, Mikolaj $\mathrm{MB}$, et al. Ambient air pollution exaggerates adipose inflammation and insulin resistance in a mouse model of diet-induced obesity. Circulation. 2009;119(4):538-46. https://doi.org/10.1161/ circulationaha.108.799015.

115. Kramer U, Herder C, Sugiri D, Strassburger K, Schikowski T, Ranft U, et al. Traffic-related air pollution and incident type 2 diabetes: results from the SALIA cohort study. Environ Health Perspect. 2010;118(9):1273-9. https://doi.org/10.1289/ehp. 0901689.

116. Longnecker MP, Daniels JL. Environmental contaminants as etiologic factors for diabetes. Environ Health Perspect. 2001;109(Suppl 6):871-6. https://doi.org/10.1289/ehp. 01109 s6871.

117. Coyne T, Ibiebele TI, Baade PD, Dobson A, McClintock C, Dunn $\mathrm{S}$, et al. Diabetes mellitus and serum carotenoids: findings of a population-based study in Queensland, Australia. Am J Clin Nutr. 2005;82(3):685-93. https://doi.org/10.1093/ajcn.82.3.685.

118. Salonen JT, Nyyssonen K, Tuomainen TP, Maenpaa PH, Korpela $\mathrm{H}$, Kaplan GA, et al. Increased risk of non-insulin dependent diabetes mellitus at low plasma vitamin E concentrations: a four year follow up study in men. BMJ (Clinical research ed). 1995;311(7013):1124-7.

119. Rahimi R, Nikfar S, Larijani B, Abdollahi M. A review on the role of antioxidants in the management of diabetes and its complications. Biomed Pharmacother. 2005;59(7):365-73. https://doi.org/ 10.1016/j.biopha.2005.07.002.

120. Law KP, Zhang H. The pathogenesis and pathophysiology of gestational diabetes mellitus: Deductions from a three-part longitudinal metabolomics study in China. Clin Chim Acta. 2017;468:6070. https://doi.org/10.1016/j.cca.2017.02.008.

121. Lauenborg J, Hansen T, Jensen DM, Vestergaard H, MolstedPedersen L, Hornnes P, et al. Increasing incidence of diabetes after gestational diabetes: a long-term follow-up in a Danish population. Diabetes Care. 2004;27(5):1194-9.
122. Homko C, Sivan E, Chen X, Reece EA, Boden G. Insulin secretion during and after pregnancy in patients with gestational diabetes mellitus. J Clin Endocrinol Metab. 2001;86(2):568-73. https:// doi.org/10.1210/jcem.86.2.7137.

123. Kautzky-Willer A, Prager R, Waldhausl W, Pacini G, Thomaseth $\mathrm{K}$, Wagner OF, et al. Pronounced insulin resistance and inadequate beta-cell secretion characterize lean gestational diabetes during and after pregnancy. Diabetes Care. 1997;20(11):1717-23.

124. Buchanan TA, Xiang AH. Gestational diabetes mellitus. J Clin Invest. 2005;115(3):485-91. https://doi.org/10.1172/jci24531.

125. Colomiere M, Permezel M, Riley C, Desoye G, Lappas M. Defective insulin signaling in placenta from pregnancies complicated by gestational diabetes mellitus. Eur J Endocrinol. 2009;160(4):567-78. https://doi.org/10.1530/eje-09-0031.

126. Oztekin $\mathrm{O}$. New insights into the pathophysiology of gestational diabetes mellitus: possible role of human leukocyte antigen-G. Med Hypotheses. 2007;69(3):526-30. https://doi.org/10.1016/j. mehy.2007.01.054.

127. Catalano PM, Tyzbir ED, Sims EA. Incidence and significance of islet cell antibodies in women with previous gestational diabetes. Diabetes Care. 1990;13(5):478-82.

128. Freeze HH. Genetic defects in the human glycome. Nat Rev Genet. 2006;7(7):537-51. https://doi.org/10.1038/nrg1894.

129. Varki A. Biological roles of oligosaccharides: all of the theories are correct. Glycobiology. 1993;3(2):97-130. https://doi.org/10. 1093/glycob/3.2.97.

130. Dwek RA. Glycobiology: Toward Understanding the Function of Sugars. Chem Rev. 1996;96(2):683-720.

131. Bertozzi CR, Kiessling LL. Chemical glycobiology. Science. 2001;291(5512):2357-64.

132. Rudd PM, Elliott T, Cresswell P, Wilson IA, Dwek RA. Glycosylation and the immune system. Science. 2001;291(5512):2370-6.

133. Talbot P, Shur BD, Myles DG. Cell adhesion and fertilization: steps in oocyte transport, sperm-zona pellucida interactions, and sperm-egg fusion. Biol Reprod. 2003;68(1):1-9.

134. Schachter H. Coordination between enzyme specificity and intracellular compartmentation in the control of protein-bound oligosaccharide biosynthesis. 1984;51(2):133-45. https://doi.org/10. 1111/j.1768-322X.1984.tb00292.x.

135. Zhang L, Luo S, Zhang B. Glycan analysis of therapeutic glycoproteins. MAbs. 2016;8(2):205-15. https://doi.org/10.1080/ 19420862.2015.1117719.

136. Sharon N. Carbohydrates. Sci Am. 1980;243(5):90-116.

137. Hart GW, Holt GD, Haltiwanger RS. Nuclear and cytoplasmic glycosylation: novel saccharide linkages in unexpected places. Trends Biochem Sci. 1988;13(10):380-4.

138. Dabauvalle MC, Schulz B, Scheer U, Peters R. Inhibition of nuclear accumulation of karyophilic proteins in living cells by microinjection of the lectin wheat germ agglutinin. Exp Cell Res. 1988;174(1):291-6.

139. Spiro RG. [2] Characterization of carbohydrate units of glycoproteins. Methods in Enzymology. Academic Press; 1966. p. 26-52.

140. Xu AY, Melton LD, Ryan TM, Mata JP, Jameson GB, Rekas A, et al. Sugar-coated proteins: the importance of degree of polymerisation of oligo-galacturonic acid on protein binding and aggregation. Soft Matter. 2017;13(14):2698-707. https://doi.org/10.1039/ c6sm02660e.

141. Vasan S, Zhang X, Zhang X, Kapurniotu A, Bernhagen J, Teichberg S, et al. An agent cleaving glucose-derived protein crosslinks in vitro and in vivo. Nature. 1996;382(6588):275-8. https://doi.org/10.1038/382275a0.

142. Stanley P. Glycosylation engineering. Glycobiology. 1992;2(2): 99-107. https://doi.org/10.1093/glycob/2.2.99.

143. Hounsell EF, Davies MJ, Renouf DV. O-linked protein glycosylation structure and function. Glycoconj J. 1996;13(1):19-26. 
144. Donald AS. A-active trisaccharides isolated from A1 and A2 blood-group-specific glycoproteins. Eur J Biochem. 1981;120(2):243-9.

145. Anderson RA, Lovrien RE. Glycophorin is linked by band 4.1 protein to the human erythrocyte membrane skeleton. Nature. 1984;307(5952):655-8.

146. Blom N, Sicheritz-Ponten T, Gupta R, Gammeltoft S, Brunak S. Prediction of post-translational glycosylation and phosphorylation of proteins from the amino acid sequence. Proteomics. 2004;4(6): 1633-49. https://doi.org/10.1002/pmic.200300771.

147. Holt GD, Hart GW. The subcellular distribution of terminal Nacetylglucosamine moieties. Localization of a novel proteinsaccharide linkage, O-linked GlcNAc. J Biol Chem. 1986;261(17):8049-57.

148. Hart GW. Dynamic O-linked glycosylation of nuclear and cytoskeletal proteins. Annu Rev Biochem. 1997;66(1):315-35. https:// doi.org/10.1146/annurev.biochem.66.1.315.

149. Snow DM, Hart GW. Nuclear and Cytoplasmic Glycosylation. In: Jeon KW, editor. International Review of Cytology. Academic Press; 1998. p. 43-74.

150. Roth J, Wang Y, Eckhardt AE, Hill RL. Subcellular localization of the UDP-N-acetyl-D-galactosamine: polypeptide Nacetylgalactosaminyltransferase-mediated O-glycosylation reaction in the submaxillary gland. Proc Natl Acad Sci U S A. 1994;91(19):8935-9.

151. Asker N, Baeckstrom D, Axelsson MA, Carlstedt I, Hansson GC. The human MUC2 mucin apoprotein appears to dimerize before O-glycosylation and shares epitopes with the 'insoluble' mucin of rat small intestine. The Biochemical Journal. 1995;308(Pt 3):87380.

152. Clausen H, Bennett EP. A family of UDP-GalNAc: polypeptide $\mathrm{N}$-acetylgalactosaminyl-transferases control the initiation of mucin-type O-linked glycosylation. Glycobiology. 1996;6(6): 635-46.

153. Hart GW, Haltiwanger RS, Holt GD, Kelly WG. Glycosylation in the nucleus and cytoplasm. Annu Rev Biochem. 1989;58(1):84174. https://doi.org/10.1146/annurev.bi.58.070189.004205.

154. Haltiwanger RS, Blomberg MA, Hart GW. Glycosylation of nuclear and cytoplasmic proteins. Purification and characterization of a uridine diphospho-N-acetylglucosamine:polypeptide beta-Nacetylglucosaminyltransferase. J Biol Chem. 1992;267(13):900513.

155. Roquemore EP, Chevrier MR, Cotter RJ, Hart GW. Dynamic OGlcNAcylation of the small heat shock protein alpha B-crystallin. Biochemistry. 1996;35(11):3578-86. https://doi.org/10.1021/ bi951918j.

156. Maeda Y, Kinoshita T. Structural remodeling, trafficking and functions of glycosylphosphatidylinositol-anchored proteins. Prog Lipid Res. 2011;50(4):411-24. https://doi.org/10.1016/j.plipres. 2011.05.002.

157. Orlean P, Menon AK. Thematic review series: lipid posttranslational modifications. GPI anchoring of protein in yeast and mammalian cells, or: how we learned to stop worrying and love glycophospholipids. J Lipid Res. 2007;48(5):993-1011. https:// doi.org/10.1194/jlr.R700002-JLR200.

158. Berger EG, Buddecke E, Kamerling JP, Kobata A, Paulson JC, Vliegenthart JF. Structure, biosynthesis and functions of glycoprotein glycans. Experientia. 1982;38(10):1129-62. https://doi.org/ $10.1007 / \mathrm{bf} 01959725$.

159. Iwase H. Variety and microheterogeneity in the carbohydrate chains of glycoproteins. The International Journal of Biochemistry. 1988;20(5):479-91.

160. Gavel Y, von Heijne G. Sequence differences between glycosylated and non-glycosylated Asn-X-Thr/Ser acceptor sites: implications for protein engineering. Protein Eng. 1990;3(5):433-42.
161. Miletich JP, Broze GJ Jr. Beta protein C is not glycosylated at asparagine 329 . The rate of translation may influence the frequency of usage at asparagine-X-cysteine sites. J Biol Chem. 1990;265(19):11397-404.

162. Kasturi L, Eshleman JR, Wunner WH, Shakin-Eshleman SH. The hydroxy amino acid in an Asn-X-Ser/Thr sequon can influence Nlinked core glycosylation efficiency and the level of expression of a cell surface glycoprotein. J Biol Chem. 1995;270(24):14756-61.

163. Kobata A. Structures and functions of the sugar chains of glycoproteins. Eur J Biochem. 1992;209(2):483-501.

164. Lis H, Sharon N. Soybean agglutinin-a plant glycoprotein. Structure of the carboxydrate unit. J Biol Chem. 1978;253(10): 3468-76.

165. Navazio L, Baldan B, Mariani P, Gerwig GJ, Vliegenthart JF. Primary structure of the N-linked carbohydrate chains of Calreticulin from spinach leaves. Glycoconj J. 1996;13(6):97783.

166. Weerapana E, Imperiali B. Asparagine-linked protein glycosylation: from eukaryotic to prokaryotic systems. Glycobiology. 2006;16(6):91r-101r. https://doi.org/10.1093/glycob/cwj099.

167. Hofsteenge J, Muller DR, de Beer T, Loffler A, Richter WJ, Vliegenthart JF. New type of linkage between a carbohydrate and a protein: C-glycosylation of a specific tryptophan residue in human RNase Us. Biochemistry. 1994;33(46):13524-30.

168. Doucey MA, Hess D, Cacan R, Hofsteenge J. Protein Cmannosylation is enzyme-catalysed and uses dolichylphosphate-mannose as a precursor. Mol Biol Cell. 1998;9(2): 291-300.

169. Krieg J, Hartmann S, Vicentini A, Gläsner W, Hess D, Hofsteenge J. Recognition signal for C-mannosylation of Trp- 7 in RNase 2 consists of sequence Trp-X-X-Trp. Mol Biol Cell. 1998;9(2):301-9.

170. Altmann F. More than silk and honey-or, can insect cells serve in the production of therapeutic glycoproteins? Glycoconj J. 1997;14(5):643-6

171. Lerouge P, Cabanes-Macheteau M, Rayon C, Fischette-Laine AC, Gomord V, Faye L. N-glycoprotein biosynthesis in plants: recent developments and future trends. Plant Mol Biol. 1998;38(1-2):31-48.

172. Holmberg CG, Laurell CB. Investigations in serum copper; nature of serum copper and its relation to the iron-binding protein in human serum. Acta Chem Scand. 1947;1(10):944-50.

173. Kelly JJ, Alpers DH. Blood group antigenicity of purified human intestinal disaccharidases. J Biol Chem. 1973;248(23):8216-21.

174. Abu-Qarn M, Eichler J, Sharon N. Not just for Eukarya anymore: protein glycosylation in Bacteria and Archaea. Curr Opin Struct Biol. 2008;18(5):544-50. https://doi.org/10.1016/j.sbi.2008.06.010.

175. Spiro RG. Protein glycosylation: nature, distribution, enzymatic formation, and disease implications of glycopeptide bonds. Glycobiology. 2002;12(4):43R-56R.

176. Dutta D, Mandal C, Mandal C. Unusual glycosylation of proteins: Beyond the universal sequon and other amino acids. Biochim Biophys Acta, Gen Subj. 2017;1861(12):3096-108. https://doi. org/10.1016/j.bbagen.2017.08.025.

177. Li C, Wang LX. Chemoenzymatic Methods for the Synthesis of Glycoproteins. Chem Rev. 2018;118(17):8359-413. https://doi. org/10.1021/acs.chemrev.8b00238.

178. Zachara NE, Hart GW. The emerging significance of O-GlcNAc in cellular regulation. Chem Rev. 2002;102(2):431-8.

179. Hart GW, Slawson C, Ramirez-Correa G, Lagerlof O. Cross talk between O-GlcNAcylation and phosphorylation: roles in signaling, transcription, and chronic disease. Annu Rev Biochem. 2011;80:825-58. https://doi.org/10.1146/annurev-biochem060608-102511.

180. Sinclair AM, Elliott S. Glycoengineering: the effect of glycosylation on the properties of therapeutic proteins. J Pharm Sci. 2005;94(8):1626-35. https://doi.org/10.1002/jps.20319. 
181. Cunningham AS. Morbidity in breast-fed and artificially fed infants. II. J Pediatr. 1979;95(5 Pt 1):685-9. https://doi.org/10.1016/ S0022-3476(79)80711-8

182. Kovar MG, Serdula MK, Marks JS, Fraser DW. Review of the epidemiologic evidence for an association between infant feeding and infant health. Pediatrics. 1984;74(4 Pt 2):615-38.

183. Jason JM, Nieburg P, Marks JS. Mortality and infectious disease associated with infant-feeding practices in developing countries. Pediatrics. 1984;74(4 Pt 2):702-27.

184. Egge H. The diversity of oligosaccharides in human milk. In: Renner B, Sawatzki G, editors. New Perspectives in Infant Nutrition. Stuttgart, New York: Georg Thieme Verlag, 1993, pp $12-26$.

185. Kunz C. Rudloff S. Biological Functions of Oligosaccharides in Human Milk. 1993;82(12):903-12. https://doi.org/10.1111/j. 1651-2227.1993.tb12597.x.

186. Wege H, Siddell S, ter Meulen V. The biology and pathogenesis of coronaviruses. Curr Top Microbiol Immunol. 1982;99:165-200.

187. Spaan W, Cavanagh D, Horzinek MC. Coronaviruses: structure and genome expression. J Gen Virol. 1988;69 ( Pt 12)(12):293952. https://doi.org/10.1099/0022-1317-69-12-2939.

188. Pachuk CJ, Bredenbeek PJ, Zoltick PW, Spaan WJ, Weiss SR. Molecular cloning of the gene encoding the putative polymerase of mouse hepatitis coronavirus, strain A59. Virology. 1989;171(1):141-8.

189. Siddell SG. Coronavirus JHM: tryptic peptide fingerprinting of virion proteins and intracellular polypeptides. J Gen Virol. 1982;62 (Pt 2)(2):259-69. https://doi.org/10.1099/0022-1317-62$2-259$.

190. Frana MF, Behnke JN, Sturman LS, Holmes KV. Proteolytic cleavage of the E2 glycoprotein of murine coronavirus: hostdependent differences in proteolytic cleavage and cell fusion. $\mathrm{J}$ Virol. 1985;56(3):912-20.

191. Routledge E, Stauber R, Pfleiderer M, Siddell SG. Analysis of murine coronavirus surface glycoprotein functions by using monoclonal antibodies. J Virol. 1991;65(1):254-62.

192. Quattrocchi CC, Wannenes F, Persico AM, Ciafre SA, D'Arcangelo G, Farace MG, et al. Reelin is a serine protease of the extracellular matrix. J Biol Chem. 2002;277(1):303-9. https:// doi.org/10.1074/jbc.M106996200.

193. Fatemi SH. Reelin glycoprotein: structure, biology and roles in health and disease. Mol Psychiatry. 2005;10(3):251-7. https:// doi.org/10.1038/sj.mp.4001613.

194. Wacher VJ, Wu CY, Benet LZ. Overlapping substrate specificities and tissue distribution of cytochrome P450 3A and P-glycoprotein: implications for drug delivery and activity in cancer chemotherapy. Mol Carcinog. 1995;13(3):129-34.

195. Parasrampuria DA, Lantz MV, Benet LZ. A human lymphocyte based ex vivo assay to study the effect of drugs on P-glycoprotein (P-gp) function. Pharm Res. 2001;18(1):39-44.

196. Diaz-Borjon A, Richaud-Patin Y. Alvarado de la Barrera C, JakezOcampo J, Ruiz-Arguelles A, Llorente L. Multidrug resistance-1 (MDR-1) in rheumatic autoimmune disorders. Part II: Increased Pglycoprotein activity in lymphocytes from systemic lupus erythematosus patients might affect steroid requirements for disease control. Joint, Bone, Spine : Revue du Rhumatisme. 2000;67(1):40-8.

197. Wasilewska AM, Zoch-Zwierz WM, Pietruczuk M. Expression of P-glycoprotein in lymphocytes of children with nephrotic syndrome treated with glucocorticoids. Eur J Pediatr. 2006;165(12): 839-44. https://doi.org/10.1007/s00431-006-0177-1.

198. Bernard BA, Yamada KM, Olden K. Carbohydrates selectively protect a specific domain of fibronectin against proteases. J Biol Chem. 1982;257(14):8549-54.

199. Kodama S, Tsujimoto M, Tsuruoka N, Sugo T, Endo T, Kobata A. Role of sugar chains in the in-vitro activity of recombinant human interleukin 5. Eur J Biochem. 1993;211(3):903-8.
200. Runkel L, Meier W, Pepinsky RB, Karpusas M, Whitty A, Kimball K, et al. Structural and functional differences between glycosylated and non-glycosylated forms of human interferonbeta (IFN-beta). Pharm Res. 1998;15(4):641-9.

201. Elliott S, Lorenzini T, Asher S, Aoki K, Brankow D, Buck L, et al. Enhancement of therapeutic protein in vivo activities through glycoengineering. Nat Biotechnol. 2003;21(4):414-21. https:// doi.org/10.1038/nbt799.

202. Tsuda E, Kawanishi G, Ueda M, Masuda S, Sasaki R. The role of carbohydrate in recombinant human erythropoietin. Eur J Biochem. 1990;188(2):405-11.

203. Narhi LO, Arakawa T, Aoki KH, Elmore R, Rohde MF, Boone T, et al. The effect of carbohydrate on the structure and stability of erythropoietin. J Biol Chem. 1991;266(34):23022-6.

204. Endo Y, Nagai H, Watanabe Y, Ochi K, Takagi T. Heat-induced aggregation of recombinant erythropoietin in the intact and deglycosylated states as monitored by gel permeation chromatography combined with a low-angle laser light scattering technique. J Biochem. 1992;112(5):700-6.

205. Uchida E, Morimoto K, Kawasaki N, Izaki Y, Abdu Said A, Hayakawa T. Effect of active oxygen radicals on protein and carbohydrate moieties of recombinant human erythropoietin. Free Radic Res. 1997;27(3):311-23.

206. Elliott S, Chang D, Delorme E, Eris T, Lorenzini T. Structural requirements for additional $\mathrm{N}$-linked carbohydrate on recombinant human erythropoietin. J Biol Chem. 2004;279(16):16854-62. https://doi.org/10.1074/jbc.M311095200.

207. Egrie JC, Browne JK. Development and characterization of novel erythropoiesis stimulating protein (NESP). Br J Cancer. 2001;84(Suppl 1):3-10. https://doi.org/10.1054/bjoc.2001.1746.

208. Goochee CF, Gramer MJ, Andersen DC, Bahr JB, Rasmussen JR. The oligosaccharides of glycoproteins: bioprocess factors affecting oligosaccharide structure and their effect on glycoprotein properties. Biotechnology (N Y). 1991;9(12):1347-55.

209. Kiessling LL, Splain RA. Chemical approaches to glycobiology. Annu Rev Biochem. 2010;79:619-53. https://doi.org/10.1146/ annurev.biochem.77.070606.100917.

210. D'Antonio M, Borrelli F, Datola A, Bucci R, Mascia M, Polletta P, et al. Biological characterization of recombinant human follicle stimulating hormone isoforms. Human Reproduction (Oxford, England). 1999;14(5):1160-7.

211. Creus S, Chaia Z, Pellizzari EH, Cigorraga SB, Ulloa-Aguirre A, Campo S. Human FSH isoforms: carbohydrate complexity as determinant of in-vitro bioactivity. Mol Cell Endocrinol. 2001;174(1-2):41-9.

212. Ziltener HJ, Clark-Lewis I, Jones AT, Dy M. Carbohydrate does not modulate the in vivo effects of injected interleukin-3. Exp Hematol. 1994;22(11):1070-5.

213. Fukuda MN, Sasaki H, Lopez L, Fukuda M. Survival of recombinant erythropoietin in the circulation: the role of carbohydrates. Blood. 1989;73(1):84-9.

214. Wang M, Yan W, Liu Y, Hu H, Sun Q, Chen X, et al. Erythropoietin ameliorates diabetes-associated cognitive dysfunction in vitro and in vivo. Sci Rep. 2017;7(1):2801. https:// doi.org/10.1038/s41598-017-03137-6.

215. Stowers AW, Chen Lh LH, Zhang Y, Kennedy MC, Zou L, Lambert L, et al. A recombinant vaccine expressed in the milk of transgenic mice protects Aotus monkeys from a lethal challenge with Plasmodium falciparum. Proc Natl Acad Sci U S A. 2002;99(1):339-44. https://doi.org/10.1073/pnas.012590199.

216. Alexander S, Elder JH. Carbohydrate dramatically influences immune reactivity of antisera to viral glycoprotein antigens. Science. 1984;226(4680):1328-30.

217. Feizi T, Childs RA. Carbohydrates as antigenic determinants of glycoproteins. The Biochemical Journal. 1987;245(1):1-11. 
218. Savolainen J, Koivikko A, Kalimo K, Nieminen E, Viander M. $\mathrm{IgE}, \operatorname{IgA}$ and $\operatorname{IgG}$ antibodies and delayed skin response towards Candida albicans antigens in atopics with and without saprophytic growth. Clin Exp Allergy. 1990;20(5):549-54.

219. Rudd PM, Morgan BP, Wormald MR, Harvey DJ, van den Berg $\mathrm{CW}$, Davis SJ, et al. The glycosylation of the complement regulatory protein, human erythrocyte CD59. J Biol Chem. 1997;272(11):7229-44.

220. Imperiali B, O'Connor SE. Effect of N-linked glycosylation on glycopeptide and glycoprotein structure. Curr Opin Chem Biol. 1999;3(6):643-9.

221. DeKoster GT, Robertson AD. Thermodynamics of unfolding for Kazal-type serine protease inhibitors: entropic stabilization of ovomucoid first domain by glycosylation. Biochemistry. 1997;36(8):2323-31. https://doi.org/10.1021/bi962580b.

222. Wyss DF, Choi JS, Li J, Knoppers MH, Willis KJ, Arulanandam AR, et al. Conformation and function of the N-linked glycan in the adhesion domain of human CD2. Science. 1995;269(5228):1273-8.

223. van Zuylen CW, de Beer T, Leeflang BR, Boelens R, Kaptein R, Kamerling JP et al. Mobilities of the inner three core residues and the Man(alpha 1-6) branch of the glycan at Asn 78 of the alphasubunit of human chorionic gonadotropin are restricted by the protein. Biochemistry. 1998;37(7):1933-1940. doi:https://doi.org/ 10.1021/bi9718548.

224. Erbel PJ, Karimi-Nejad Y, De Beer T, Boelens R, Kamerling JP, Vliegenthart JF. Solution structure of the alpha-subunit of human chorionic gonadotropin. Eur J Biochem. 1999;260(2):490-8.

225. van Zuylen CWEM, Kamerling JP, Vliegenthart JFG. Glycosylation beyond the Asn78-Linked GlcNAc Residue Has a Significant Enhancing Effect on the Stability of the $\alpha$ Subunit of Human Chorionic Gonadotropin. Biochem Biophys Res Commun. 1997;232(1):117-20. https://doi.org/10.1006/bbrc. 1997.6241.

226. Pari L, Ashokkumar N. Glycoprotein changes in non-insulin dependent diabetic rats: Effect of N-benzoyl-D-phenylalanine and metformin. Therapie. 2006;61(2):125-31. https://doi.org/10. 2515/therapie:2006022.

227. Balan K, Pratheebaa P, Jebastin T, Sundarabaalaji N, Liu X, Palvannan T. Beneficial protective effects of 2-allyl amino 4methyl sulfanyl butyric acid on glucose metabolism and glycoprotein components in streptozotocin induced diabetic rats with molecular modeling. Toxicology Research. 2016;5(2):399-406.

228. Pari L, Saravanan R. The effect of succinic acid monoethyl ester on plasma and tissue glycoproteins in streptozotocin-nicotinamide induced diabetic rats. J Appl Biomed. 2006;4(4):187-96.

229. Sacan O, Turkyilmaz IB, Bayrak BB, Mutlu O, Akev N, Yanardag R. Zinc supplementation ameliorates glycoprotein components and oxidative stress changes in the lung of streptozotocin diabetic rats. BioMetals. 2016;29(2):239-48. https://doi.org/10.1007/ s10534-016-9911-y.

230. Tabatabaei-Malazy O, Larijani B, Abdollahi M. Targeting metabolic disorders by natural products. J Diabetes Metab Disord. 2015;14:57. https://doi.org/10.1186/s40200-015-0184-8.

231. Veeramani C, Al-Numair KS, Alsaif MA, Chandramohan G, AlNumair NS, Pugalendi KV. Protective effect of Cardiospermum halicacabum leaf extract on glycoprotein components on STZinduced hyperglycemic rats. Asian Pac J Trop Med. 2012;5(12): 939-44. https://doi.org/10.1016/S1995-7645(12)60178-3.

232. Govindasamy C, Al-Numair KS, Alsaif MA, Viswanathan KP. Influence of 3-hydroxymethyl xylitol, a novel antidiabetic compound isolated from Casearia esculenta (Roxb.) root, on glycoprotein components in streptozotocin-diabetic rats. J Asian Nat Prod Res. 2011;13(8):700-6. https://doi.org/10.1080/10286020.2011. 585157.

233. Basha RH, Sankaranarayanan C. Protective role of $\beta$ caryophyllene, a sesquiterpene lactone on plasma and tissue glycoprotein components in streptozotocin-induced hyperglycemic rats. J Acute Med.. 2015;5(1):9-14. https://doi.org/10.1016/ j.jacme.2015.02.001

234. Elanchezhiyan C, Kumaravel K, Ahmad Bhat B, Sethupathy S. Protective role of Helicteres isora plant extract on plasma and tissue glycoprotein components in streptozotocin induced hyperglycemic rats. Pharm J. 2014;6(4):86-91. https://doi.org/10.5530/ pj.2014.4.14.

235. Chandramohan R, Saravanan S, Pari L. Beneficial effects of tyrosol on altered glycoprotein components in streptozotocininduced diabetic rats. Pharm Biol. 2017;55(1):1631-7. https:// doi.org/10.1080/13880209.2017.1315603.

236. Ramkumar KM, Rajaguru P, Latha M, Ananthan R. Ethanol extract of Gymnema montanum leaves reduces glycoprotein components in experimental diabetes. Nutr Res. 2007;27(2):97-103. https://doi.org/10.1016/j.nutres.2006.12.010.

237. Prakasam A, Sethupathy S, Pugalendi KV. Influence of Casearia esculenta root extract on glycoprotein components in streptozotocin diabetic rats. Pharmazie. 2005;60(3):229-32.

238. Pavana P, Sethupathy S, Manoharan S. Protective role of Tephrosia purpurea ethanolic seed extract on glycoprotein components in Streptozotocin induced diabetic rats. Int J Pharmacol. 2008;4(2):114-9. https://doi.org/10.3923/ijp.2008.114.119.

239. Pari L, Murugan P. Changes in glycoprotein components in streptozotocin - Nicotinamide induced type 2 diabetes: Influence of tetrahydrocurcumin from curcuma longa. Plant Foods Hum Nutr. 2007;62(1):25-9. https://doi.org/10.1007/s11130-006-0037-1.

240. Pari L, Karthikesan K. Protective role of tetrahydrocurcumin and chlorogenic acid on glycoprotein changes in streptozotocinnicotinamide-induced diabetic rats. Journal of Pharmaceutical Sciences and Research. 2009;1(4):173-80.

241. Ramesh B, Pugalendi KV. Influence of umbelliferone on glycoprotein components in diabetic rats. Toxicol Mech Methods. 2007;17(3):153-9. https://doi.org/10.1080/15376510600899555.

242. Sulaiman GM, Al-Amiery AAH, Mohammed AA, Al-Temimi AA. The effect of cherry sticks extract on the levels of glycoproteins in alloxan-induced experimental diabetic mice. Ann Clin Lab Sci. 2012;42(1):34-41.

243. Sundaram R, Naresh R, Shanthi P, Sachdanandam P. Antihyperglycemic effect of iridoid glucoside, isolated from the leaves of Vitex negundo in streptozotocin-induced diabetic rats with special reference to glycoprotein components. Phytomedicine. 2012;19(3-4):211-6. https://doi.org/10.1016/j. phymed.2011.10.006.

244. Saravanan G, Moses MF, Karthickeyan S, Senthilkumar GP. Influence of Terminalia belerica fruits extracts on glycoprotein components in streptozotocin induced diabetic rats. Biosciences Biotechnology Research Asia. 2009;6(2):727-32.

245. Senthilkumar GP, Subramanian SP. Biochemical studies on the effect of Terminalia chebula on the levels of glycoproteins in streptozotocin-induced experimental diabetes in rats. J Appl Biomed. 2008;6(2):105-15.

246. Saravanan G, Ponmurugan P, Senthil Kumar GP, Rajarajan T. Antidiabetic effect of S-allylcysteine: Effect on plasma and tissue glycoproteins in experimental diabetes. Phytomedicine. 2010;17(14):1086-9. https://doi.org/10.1016/j.phymed.2010.04.008.

247. Sacan O, Ertik O, Ipci Y, Kabasakal L, Sener G, Yanardag R. Protective effect of chard extract on glycoprotein compounds and enzyme activities in streptozotocin-induced hyperglycemic rat lungs. Bulg Chem Commun. 2018;50(1):119-23.

Publisher's note Springer Nature remains neutral with regard to jurisdictional claims in published maps and institutional affiliations. 